\title{
The Value of Advice: Evidence from Mobile Phone- Based Agricultural Extension
}

\section{Citation}

Cole, Shawn A., and A. Nilesh Fernando. "The Value of Advice: Evidence from Mobile PhoneBased Agricultural Extension." Harvard Business School Working Paper, No. 13-047, November 2012.

\section{Permanent link}

http://nrs.harvard.edu/urn-3:HUL.InstRepos:10007889

\section{Terms of Use}

This article was downloaded from Harvard University's DASH repository, and is made available under the terms and conditions applicable to Open Access Policy Articles, as set forth at http:// nrs.harvard.edu/urn-3:HUL.InstRepos:dash.current.terms-of-use\#OAP

\section{Share Your Story}

The Harvard community has made this article openly available.

Please share how this access benefits you. Submit a story.

Accessibility 
H A R VARD D B U S I N E S S S C H O O L

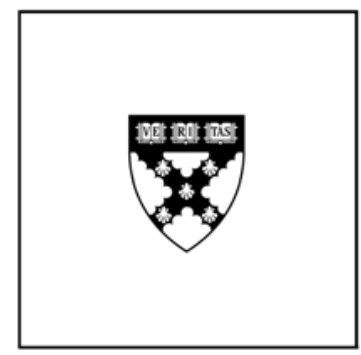

\section{The Value of Advice: Evidence from Mobile Phone- Based Agricultural Extension}

Shawn A. Cole

A. Nilesh Fernando

\section{Working Paper}

13-047

November 21, 2012 


\title{
The Value of Advice: Evidence from Mobile Phone-Based Agricultural Extension
}

\author{
Shawn A. Cole and A. Nilesh Fernando *
}

November 21, 2012

\begin{abstract}
Attempts to explain the astonishing differences in agricultural productivity around the world typically focus on farm size, farmer risk aversion, and credit constraints, with an emphasis on how they might serve to limit technology adoption. This paper takes a different tack: can managerial practices explain this variation in productivity? A randomized evaluation of the introduction of a mobile-phone based agricultural consulting service, "Avaaj Otalo (AO)" to cotton farmers in Gujarat, India, reveals the following. Demand for agricultural advice is high, with more than half of farmers calling AO in the first seven months. Farmers offered the service turn less often to other farmers and input sellers for agricultural advice. Management practices change as well: we observe an increase in the adoption of more effective pesticides, and reduced expenditure on less effective and hazardous pesticides. Treated farmers also sow a significantly larger quantity of cumin, a lucrative but risky crop. Interestingly, use of the service is increasing in the level of farmer education, but education levels do not affect the size of treatment effects. Farmers appear willing to follow advice without understanding why the advice is correct: the average respondent does not demonstrate improved agricultural knowledge, though there is some evidence educated farmers learn from the service.

\footnotetext{
${ }^{*}$ Harvard Business School (scole@hbs.edu) and Harvard Kennedy School (asanga_fernando@hks.harvard.edu). We gratefully acknowledge support from the Australian Agency for International Development, and USAID. Shawn Cole acknowledge support from the Division of Faculty Research and Development at HBS. We thank the Development Support Centre (DSC) in Ahmedabad and especially Paresh Dave, Natubhai Makwana and Sachin Oza for their assistance and cooperation. Additionally, we thank Neil Patel and Awaaz.De for hosting the AO system and the Centre for Micro Finance (CMF), Chennai and Shahid Vaziralli for support in administering the evaluation. We are especially indebted to Niharika Singh, Tanaya Devi, and HK Seo for excellent research assistance, and to Tarun Pokiya for his agricultural expertise and management of the AO system. This paper has benefited from comments from seminar participants at Harvard, MIT, NEUDC, and IFPRI
} 


\section{JEL Classification Numbers: O12,O13,Q16.}

\section{Introduction}

Agricultural productivity varies dramatically around the world. For example, India is the second largest producer of cotton in the world, after China. Yet, Indian cotton productivity ranks $78^{\text {th }}$ in the world, with yields only one-third as large as those in China. While credit constraints, missing insurance markets, and poor infrastructure may account for some of this disparity, a variety of observers have pointed out the possibility that suboptimal agricultural practices and poor management may also be to blame (Jack (2011)).

This is not a novel idea. For decades, the Government of India, like most governments in the developing world, has operated a system of agricultural extension, intended to spread information on new agricultural practices and technologies, through a large work force of public extension agents. However, evidence of the efficacy of these extension services is quite limited. In India, dispersed rural populations, monitoring difficulties and a lack of accountability hamper the efficacy of traditional extension systems: fewer than $6 \%$ of the agricultural population reports having received information from these services.

This paper examines whether the introduction of low-cost information and communications technology (ICT), able to deliver timely, relevant, and actionable information and advice to farmers at dramatically lower cost than any traditional service can improve agricultural management We evaluate Avaaj Otalo (AO), a mobile phone-based technology that allows farmers to call a hotline, ask questions and receive responses from agricultural scientists and local extension workers. Callers can also listen to answers to questions posed by other farmers. Working with the Development Support Centre (DSC), an NGO with extensive experience in delivering agricultural extension, the research team randomly 
assigned toll-free access to AO to 800 households, with an additional 400 households serving as a control group. ${ }^{1}$ The households were spread across 40 villages in Surendranagar district in Gujarat, India, and randomization occurred at the household level.

The AO service also included weekly push content, delivering time sensitive information such as weather forecasts and pest planning strategies directly to farmers. This paper presents the results from two rounds of phone surveying, which sampled 800 of the 1200 study participants, and covers events during the kharif or summer rainy season of $2011 .^{2}$

We show that $\mathrm{AO}$ had a range of important, positive effects on farmer behavior. It significantly changed farmers' sources of information for sowing and input-related decisions-in particular, farmers relied less on commissions-motivated agricultural input dealers for pesticide advice. Treated farmers were more likely to switch to a pesticide that is both more effective against pests, and dramatically less toxic to humans. Farmers benefiting from advice also changed investment decisions, demonstrating more knowledge about cumin and growing more of it.

This study makes the following contributions. We demonstrate that informational inefficiencies are real, ${ }^{3}$ and that farmers are aware they lack information: there is considerable demand for high quality agricultural information. We present the first rigorous evidence that a low-cost agricultural extension service (costing as little as US $\$ .60$ per farmer per month) can change behavior. We provide some evidence of the existence of a "digital divide." We find systematic differences in adoption and use of the service, even among a

\footnotetext{
${ }^{1}$ Of the 800 households assigned to $\mathrm{AO}, 400$ were assigned to also receive traditional agricultural extension services. This will allow us to evaluate the complementarity of in-person and ICT-based training. However, as this paper primarily uses data collected before the growing season affected by training, we focus attention on the $\mathrm{AO}$ service.

${ }^{2}$ Resource constraints precluded conducting phone surveys for al 1,200 participants each month. The entire sample is covered in the less frequent household surveys.

${ }^{3}$ Informational inefficiencies in the context of technology adoption have been defined as a situation in which farmers may not be aware of new agricultural technologies, or how they should be utilized (Jack (2011))
} 
relatively homogeneous group of farmers, and even for a technology that was specifically designed to be accessible to an illiterate population. Finally, as a methodological contribution, we demonstrate that surveying by mobile phones can be conducted effectively and cheaply (the average "all-in" cost of a phone survey was $\$ 2.51$, compared to over $\$ 10$ for a paper survey), in a developing country context. ${ }^{4}$

First, this paper contributes to an understanding of the mechanisms underlying the dramatic variation in productivity of firms and farms in developing countries, and the role of management consulting in improving productivity. These large productivity differences have in part motivated recent literature on non-aggregative growth (Banerjee-Duflo(2005), Hseih-Klenow(2009). While a large literature focuses on the microeconomics of technology adoption (for a survey, see Foster and Rosenzweig (2010)), we instead focus on whether consulting-like service can facilitate improved production practices. (Cf. Duflo, Kremer, and Robinson.) Our treatments differ from much previous work in this space in that participants receive a continuous flow of demand-oriented information, rather than a one-off provision of supply-driven information. See McKenzie and Woodruff (2012) for a discussion of training and consulting evidence for small firms in developing countries.

More specifically, this paper advances the literature on the efficacy of agricultural extension (Feder, Lau, and Slade (1987), Gandhi, Veeraraghavan, Toyama, and Ramprasad (2009), Duflo, Kremer, and Robinson (2011)). The existing literature finds mixed evidence of efficacy, though it is not clear whether this is due to variation in programs offered, or methodological challenges associated with evaluating programs without plausibly exogenous variation (Birkhaeuser, Evenson, and Feder (1991)). This paper complements recent evidence on the historical efficacy of agricultural extension in promoting the adoption of new agricultural technologies in India (Bardhan and Mookherjee (2011)), and provides

\footnotetext{
${ }^{4}$ In a related study, we test the validity of mobile-phone based surveying by randomly assigning one module of a household survey to be administered either by mobile phone, or by paper survey.
} 
guidance as to lower-cost solutions for delivering advice. To our knowledge, our study is the first rigorous evaluation of mobile phone-based extension and, more generally, the first evaluation of a demand-driven extension service delivered by any means.

This paper is organized as follows. The next section places this paper's contribution in the literature, and provides context and the details of the AO intervention. Section 3 presents the experimental design and the empirical strategy, while Section 4 presents the results from the first two rounds of phone surveying. Following this, Section 5 considers threats to the validity of the results. Section 6 discusses plausible mechanisms that might underlie the observed results, and Section 7 concludes.

\section{Context and Intervention Description}

\subsection{Agricultural Extension}

According to the World Bank, there are more than 1 million agricultural extension workers in developing countries, and public agencies have spent over $\$ 10$ billion dollars on public extension programs in the past five decades (Feder (2005)). The traditional extension model, "Training and Visit" extension, has been promoted by the World Bank throughout the developing world and is generally characterized by government-employed extension agents visiting farmers individually or in groups to demonstrate agricultural best practices (Anderson and Birner (2007)). Like many developing countries, India has a system of local agricultural research universities and district level extension centers, producing a wealth of specific knowledge. In 2010 the Government of India spent $\$ 300$ million on agricultural research, and a further $\$ 60$ million on public extension programs (RBI, 2010).

Yet, traditional extension faces several important challenges that limit its efficacy.

Spatial Dimension: Limited transportation infrastructure in rural areas and the high 
costs of delivering information in person greatly limit the reach of extension programs. The problem is particularly acute in interior villages in India, where farmers often live in houses adjacent to their plots during the agricultural cycle, creating a barrier to both the delivery and receipt of information.

Temporal Dimension: As agricultural extension is rarely provided to farmers on a recurring basis, the inability of farmers to follow-up on information delivered may limit their willingness to adopt new technologies. Infrequent and irregular meetings limit the ability to provide timely information, such as how to adapt to inclement weather or unfamiliar pest infestations.

Institutional Rigidities: In the developing world, government service providers often face institutional difficulties. The reliance on extension agents to deliver in-person information is subject to general monitoring problems in a principal-agent framework (Anderson and Feder (2007)). For example, monthly performance quotas lead agents to target the easiest-to-reach farmers, and rarely exceed targets. Political capture may also lead agents to focus outreach on groups affiliated with the local government, rather than to marginalized groups for whom the incremental benefit may be higher. Even when an extension agent reaches farmers, the information delivered must be locally relevant, and delivered in a manner that is accessible to farmers with low levels of literacy.

The importance of these constraints is difficult to overstate (Birkhaeuser, Evenson, and Feder (1991), Saito and Weidemann (1990).) A recent nationally representative survey shows that just $5.7 \%$ of farmers report receiving information about modern agricultural technologies from public extension agents in India (Glendenning, Babu, and Asenso-Okyere (2010).) This failure is only partly attributable to the misaligned incentives of agricultural extension workers; more fundamentally, it is attributable to the high cost of reaching farmers in interior rural areas. 
Finally, a potential problem is that information provision to farmers is often "topdown." This may result in an inadequate diagnosis of the difficulties currently facing farmers, as well as information that is often too technical for semi-literate farming populations. This problem may affect adoption of new technologies as well as optimal use of current technologies.

In the absence of expert advice, farmers seek out agricultural information through word of mouth, generic broadcast programming, or agricultural input dealers, who may be poorly informed or face incentives to recommend the wrong product or excessive doseage (Anderson and Birner (2007)). ${ }^{5}$

These difficulties combine to limit the reliable flow of information from agricultural research universities to farmers, and may limit their awareness of and willingness to adopt new agricultural technologies. Overcoming these "informational inefficiencies" may therefore dramatically improve agricultural productivity and farmer welfare. The emergence of mobile phone networks and the rapid growth of mobile phone ownership across South Asia and Sub-Saharan Africa has opened up the possibility of using a completely different model in delivering agricultural extension services.

\subsection{Avaaj Otalo: Mobile Phone-Based Extension}

Roughly $52 \%$ of the Indian labor force, or 270 million people, are engaged in agriculture. As approximately $36 \%$ own a mobile phone, AO could serve as many as 97 million farmers nationally, including over 9 million in Gujarat alone ${ }^{6}$. Mobile phone access has

\footnotetext{
${ }^{5}$ An audit study of 36 input dealerships in a block near our study site provides a measure of the quality of advice provided by commissions-motivated input dealers. The findings suggest that the information provided is rarely customized to specific pest management problems of the farmer, and often takes the form of ineffective pesticides that were traditionally useful, but are no longer effective against the dominant class of pests.

${ }^{6}$ These figures are calculated using estimates from the 2010-2011 Indian Ministry of Labor and the Annual Report of the Telecom Regulatory Authority of India
} 
fundamentally changed the way people communicate with each other, and has increased information flows across the country's diverse geographic areas. As coverage continues to expand in rural areas, mobile phones carry enormous promise as a means for delivering extension to the country's numerous small and marginal farmers (Aker (2011)).

Our intervention utilizes an innovative information technology service, Avaaj Otalo $(\mathrm{AO}) . \mathrm{AO}$ is an open-source platform delivered by phone, which allows information to be delivered to and shared by farmers. Farmers receive weekly push-content, which includes detailed agricultural information on weather and crop conditions that are delivered through an automated voice message.

Farmers can also call in to a toll-free hotline that connects them to the AO platform and ask questions on a variety of agricultural topics of interest to them. Staff agronomists at the Development Support Centre (DSC) - our field partner - with experience in local agricultural practices receive these requests and deliver customized advice to these farmers, via recorded voice messages. Farmers may also listen and respond to the questions their peers ask on the AO platform, which is moderated by DSC. The AO interface features a touch-tone navigation system with local language prompts, developed specifically for ease of use by semi-literate farmers. The platform, which has now been deployed in a range of domains, was initially developed as part of a Berkeley-Stanford research project on humanmachine interaction, in cooperation with the DSC in rural Gujarat (Patel, Chittamuru, Jain, Dave, and Parikh (2010)).

Mobile phone-based extension allows us to tackle many of the aforementioned problems with traditional extension. AO has the capability to reach millions of previously excluded farmers at a virtually negligible marginal cost. Farmers in isolated villages can request and receive information from $\mathrm{AO}$ at any point during the agricultural season, something they are typically unable to do under traditional extension. Farmers receive calls with 
potentially useful agricultural information on their mobile phones, and need not leave their fields to access the information. In case a farmer misses a call, she can even call back and listen to that information on the main line. AO thus largely solves the spatial problems of extension delivery discussed earlier.

A considerable innovation of $\mathrm{AO}$ is tackling the temporal problem of extension delivery. The agricultural cycle can be subject to unanticipated shocks such as weather irregularities and pest attacks, both of which require swift responses to minimize damage to a standing crop. Because farmers can call in and ask questions as frequently as they want, they can get updated and timely information on how to deal with these unanticipated shocks. This functionality may indeed increase the risk-bearing capacity of farmers by empowering them with access to consistent and quality advice.

With respect to problems of the institutional nature mentioned earlier, AO facilitates precise and low-cost monitoring. The computer platform allows easy audits of answers DSC agronomists offer, greatly limiting the agency problem. Additionally, the AO system allows for demand-driven extension, increasing the likelihood that the information is relevant and useful to farmers. Push-content is developed by polling a random set of farmers each week to elicit a representative set of concerns. In addition to this polling, the questions asked by calling in to AO also provide the information provider a sense of farmers' contemporaneous concerns. This practice of demand-oriented information provision should improve both the allocation and the likelihood of utilization of the information.

However, while AO overcomes many of the challenges of traditional extension, it eliminates in-person demonstrations, which may be a particularly effective way of conveying information about agricultural practices. A follow-up study will evaluate the extent to which in-person extension serves as a complement to AO-based extension, by providing a subset of farmers with both traditional extension administered through staff at DSC and 
toll-free access to AO.

\section{$3 \quad$ Experimental Design \& Empirical Strategy}

Chotila and Sayla, two administrative blocks ${ }^{7}$ in Surendranagar district, were chosen as the site of the study, as our field partner, DSC, had done work in the area. Lists of farmers were enumerated in 40 villages, with the criteria for selection being that they were 1.) interested in participating in the study, 2.) grew cotton, 3.) owned a mobile phone and 4.) were the chief agricultural decision maker of their household.

A sample of 1200 respondents was selected from this pool, with 30 households in each village participating in the study. Treatments were then randomly assigned at the household-level using a scratch-card lottery. The sample is split into three groups of 400 households each. The first treatment group (hereafter, AOE) receives toll-free access to $\mathrm{AO}$ in addition to traditional extension. The traditional extension component consisted of a single session lasting roughly two-and-half hours on DSC premises in Surendranagar. The second treatment group (hereafter, AO) received toll-free access to AO, but no offer of traditional agricultural extension, and a final 400 households served as the control group.

While dramatically increasing statistical power, the decision to randomize at the household rather than village level raises the possibility that the control group may also have access to information through our treatment group. This suggests that any treatment effects may in fact underestimate the value of the service. Future work will examine information spillovers, both within the respondent group and among non-study peers, in greater detail.

Baseline data was collected in June and July, 2011, and a phone survey consisting of 798 respondents was completed in November 2011, within a few days of the completion of

\footnotetext{
${ }^{7} \mathrm{~A}$ block is an administrative unit below the district level
} 
the traditional extension. The phone survey includes the entire control group, in addition to half of $\mathrm{AOE}$ and half of $\mathrm{AO}$ which were randomly selected. Apart from Table 1, in which we test for balance among the three groups, the rest of this paper reports results from the phone survey and thus our analysis is limited to the combined treatment group that was surveyed by phone. This group will be referred to as the "Treatment" group and will be labelled as "Treat" in all subsequent tables. ${ }^{8}$

To gauge balance and describe our first stage, we compute a simple difference specification of the form:

$$
y_{i v}=\alpha_{v}+\beta_{1} \text { Treat }_{i v}+\varepsilon_{i}
$$

where, $\alpha_{v}$ is a village fixed effect, Treat ${ }_{i v}$ is an indicator variable that takes on the value 1 for an individual, $i$, in village $v$ assigned to a treatment group and 0 for an individual assigned to the control group. We report robust standard errors below the coefficient estimates.

Because of random assignment, the causal effect of the intervention can be gauged by computing a standard difference-in-difference specification:

$$
y_{i v t}=\alpha_{v}+\beta_{1} \text { Treat }_{i v}+\beta_{2} \text { Post }_{t}+\beta_{3}(\text { Treat } * \text { Post })_{i v t}+\varepsilon_{i}
$$

where, $\alpha_{v}$ and Treat $_{i v}$ are as above, Post $_{t}$ is an indicator variable that takes on a value of 1 if the observation was collected after the intervention was administered and 0 if it was collected during the baseline, and $(\text { Treat } * \text { Post })_{i v t}$ is the interaction of the preceding two terms. The empirical results largely estimate (1) for the outcome variables of interest,

\footnotetext{
${ }^{8}$ The phone survey was designed to understand the overall impact of the AO service rather than to piece out differential effects of $\mathrm{AO}$ vs AOE. Power calculations suggested that a sample size of roughly 400 was necessary to detect effects of interest with $80 \%$ power; hence the phone survey data we report in this paper, comprising 200 from $\mathrm{AO}$ and 200 from AOE, may not be sufficient to distinguish the two treatments.
} 
using robust standard errors.

In addition, we explore heterogeneity in the treatment effect by estimating:

$$
y_{i v}=\alpha_{v}+\beta_{1} \text { Treat }_{i v}+\beta_{2} I\left(X_{i v}>\text { Median }\right)+\beta_{3} \text { Treat }_{i v} * I\left(X_{i v}>\text { Median }\right)+\varepsilon_{i v}
$$

where, $X_{i}$ is the variable across which we explore heterogeneity in treatment effects, and $I\left(X_{i v}>\right.$ Median $)$ a dummy equal to one when the observation is above the median level of $X_{i v}$. The results presented in the section on heterogeneous treatment effects are virtually identical when $X_{i v}$ is included as a continuous variable.

\subsection{Summary Statistics and Balance}

Table 1 contains summary statistics for age, education, landholdings, income and cotton cultivation for respondents in the study, using data from a baseline paper survey conducted in July and August of 2011. The first column reports summary statistics (mean and standard deviation) for the control group. Columns (2) and (3) report means and standard deviations for the $\mathrm{AO}$ and $\mathrm{AOE}$ groups, while columns (4) and (5) test whether the initial randomization achieved balance. Column (6) reports whether there is balance between the subset of treatment respondents surveyed by phone and the control group.

We see that respondents are on average 36 years old, have approximately 9 years of education, own roughly 6.5 acres of land, and earn $\$ 288$ a month on average.

Column (4) shows that an imbalance exists in the area of cotton planted between the AO group and the control group in 2010 but not in 2011 (both periods are prior to treatment). This difference persists in the treatment-control comparison in the subset of respondents surveyed by phone (Column 5). Analogous differences exist in the number of respondents planting wheat.

To control for the possibility that baseline cotton levels affect subsequent outcomes, 
when analyzing simple differences, we also include a specification which controls for the area of cotton cultivated in 2010, as in (3) below:

$$
y_{i v}=\alpha_{v}+\beta_{1} \text { Treat }_{i v}+\beta_{2}(\text { Area of Cotton Cultivated })_{i v}+\varepsilon_{i v}
$$

Appendix Table A4 provides a more systematic treatment of balance in our sample. We look for significant differences in baseline characteristics between the AO group and control (Column 1), the AOE group and control (Column 2), and treatment and control respondents in the phone survey (Column 3). Among the differences computed using the latter specification (examining all 1,923 baseline variables) we find that $1 \%$ are significantly

difference from zero at the $1 \%$ level, $4 \%$ are different at the $5 \%$ level of significance and $8 \%$ at the $10 \%$ level. These results confirm that the randomization was successful, and that the cotton imbalance is a result of chance rather than any systematic mistake in the randomization mechanism.

\section{Experimental Results}

In the following subsections references to the "Treatment group" are synonymous with the group of $\mathrm{AO}$ and $\mathrm{AOE}$ (400 respondents) who were surveyed by phone.

\section{Sources of Agricultural Information Prior to AO}

Table 2 provides information on farmers' reported sources of information at the baseline, which was conducted before respondents were assigned to treatment status. Column (1) provides summary statistics on information sources for cotton planting for the treatment group. While virtually all farmers planted cotton, only $32 \%$ of them reported seeking out or receiving advice on optimal practices. The treatment group was no more likely to seek out 
information. Among those who sought information on cotton planting, most relied on other farmers (82\%), with input shops the second most popular source of advice. Roughly similar patterns hold for questions about cotton fertilizer and pesticide, and wheat and cumin planting. Notably unimportant are government extension services, virtually unmentioned by farmers as a source of information. The even-numbered columns present the difference in each measure between the treatment and control group, and the standard error. There are no statistically significant differences in information sources in the baseline.

\subsection{First Stage: Take-Up and Usage of AO}

Table 4 reports the first stage. While control respondents were not barred from AO usage, only four control respondents called in to the AO line. As a result, virtually all AO usage is accounted for by respondents in the treatment group. As of the March, 2012, seven months after commencement of the service, $58 \%$ of the treatment group had called in to the AO line, making an average of 7.5 calls (Column 3). The mean usage for respondents in the treatment group is roughly 103 minutes. Additionally, $32 \%$ of the treatment group had asked a question and $16 \%$ had responded to questions.

We also see that treatment farmers have on average listened to $65 \%$, or approximately 90 minutes, of push call content. Taken together the results represent substantial induced usage for treatment farmers, though a substantial number of users may still face barriers in using AO. Subsequent training may enable these users to take advantage of AO.

Table 3 provides a categorization of the questions asked by treatment respondents during the first months of the service. (The categories are not mutually exclusive.) Unsurprisingly, a majority $(67 \%)$ of questions relate to cotton, and a majority of these focus on pest management. Across crops as well, the majority of questions relate to pest management, a topic of obvious importance to farmers. Appendix Table A2 indicates that $97 \%$ of 
farmers reported experiencing a pest attack recently. Table 3 also reports the content of push calls, which tended to focus more on cumin than other crops, and on fertilizer and pesticide use.

\subsection{Impact on Sources of Information for Agricultural Decisions}

Table 5 looks at the extent to which the provision of information through AO affected the main source of information that farmers use in making planting, fertilizer and pesticide related decisions for their cotton, cumin, and wheat crops. The table again reports summary statistics (mean and standard deviation) for the control group and the intention to treat (ITT) estimate for respondents receiving access to AO (i.e. column "Treat-Control').

It is clear that across all input-related decisions we see large and statistically significant point estimates, indicating an increase in the usage of mobile phone-based information. These effects are particularly large in the case of cotton fertilizer $(22 \%)$ and cotton pesticide (30\%) decisions, and somewhat smaller in the case of cumin planting (12\%), cotton planting (8\%) and wheat planting (5\%). Importantly, AO was not prompted to respondents as a choice for mobile phone-based information, but upon asking respondents to specify the name of their source, it was virtually always the case that they would name AO.

Print media (newspapers and magazines) and traders or commission agents were rarely if ever cited as a source of information and as such those options have been excised from the table. Consistent with section 2.2, less than $1 \%$ of all respondents cite government extension workers as a source of information across all reported agricultural decisions. This number is made all the more remarkable by the fact that Chotila block - one of the two administrative blocks in our study - has a government extension facility (Krishi Vigyan Kendra); only 27 of the 170 administrative blocks in Gujarat state have such extension facilities. If NGO extension workers are included as well, the total amount of our respondents that receive 
information from extension workers goes up to roughly $5 \%$.

As mentioned earlier, input dealers tend to be the dominant source of external information in making input-related decisions (often for lack of other sources), with $44 \%$ of the control group citing them as their main source of information for pesticide-related decisions, and $14 \%$ doing likewise for fertilizer related decisions. It is also important to note that less than $1 \%$ of control group respondents cite mobile phone-based information as their main source of information across agricultural decisions, suggesting that while mobile phone ownership is prevalent in rural India, other organizations have not been successful in delivering agricultural information through this conduit. In fact, there is an official government call center providing live agricultural advice, but farmers are either not aware of it or not satisfied with the service.

$\mathrm{AO}$ also seems to reduce the dependence of treatment respondents on other farmers for information. Across all agricultural decisions, fewer treatment farmers report their peers as their main source of information, and these effects are particularly large in the case of cotton fertilizer decisions (15\%) and cotton planting decisions (13\%).

Taken together, these results suggest that AO has been successful in establishing itself as a source of information for treatment respondents in making a variety of important agricultural decisions. These results also suggest that demand exists for agricultural information in rural Gujarat, that this information is not currently being provided via mobile phone and that farmers desire alternatives to relying on input dealers for advice. In the next sections we look at whether the provision of information through AO affected pesticide investment and usage decisions. 


\subsection{Impact on Pesticide Investment and Usage}

Table 6 reports pesticide investment decisions regarding the primary four pesticides used by study respondents - monocrotophos, acephate powder, acetamaprid and imidaclorprid. We report the difference-in-difference estimates for the difference between the treatment group and the control group with village fixed effects.

While the frequency of purchase data exists for the entire set of respondents, the actual costs only exist for a subset of this sample, as many respondents who purchase pesticides on credit, do not settle their debts until after their harvest is taken to the market and therefore do not know or cannot precisely report the costs they have incurred.

Monocrotophos and acephate powder are both organophosphate pesticides which have been widely used in India since the 1980's, and are primarily intended for treating a class of pests known as the 'bollworm complex'. However, $95 \%$ of our sample uses Bt cotton, a variety of cotton that promises immunity to bollworms but is still suspectible to 'sucking pests' such as aphids, jassids and the mealy bug.

Additionally, monocrotophos is categorized as "highly hazardous" (Class Ib) by the World Health Organization, while the other three pesticides are classed as "moderately hazardous" (Class II). Roughly $85 \%$ of the respondent group purchased monocrotophos and acephate powder (less than $10 \%$ only bought one and not the other) at baseline, and on average this accounted for $55 \%$ of total expenditure on pesticides. However, substantially fewer respondents bought the newer neonicotinoids, imidaclorprid (47\%) and acetamaprid (25\%), accounting for approximately $14 \%$ of total expenditure on pesticides.

Perhaps most interestingly we see a $10 \%$, increase in the fraction of the AO group purchasing imidacloprid relative to the control group, significant at the $5 \%$ level. Imidacloprid is a pesticide suitable for sucking pests attacks, which accounts for the vast majority of pest related shocks as demonstrated in Table A2. Additionally, we see a $20 \%$ reduction (Rs. 
280) in spending on monocrotophos relative to the control group, and a similar reduction in spending on acephate.

Table 7 analyzes the usage of pesticides. It reports the frequency (\%), quantity (liters or kg) and intensity (quantity applied per acre) of pesticide usage for monocrotophos, imidachlorpid, acetamaprid and acephate. Consistent with our estimates in Table 6, roughly $8 \%$ more respondents in the $\mathrm{AO}$ group report having used imidacloprid, significant at the $10 \%$ level. In addition, the intensity of imidacloprid usage is roughly $3 \%$ higher for treatment group respondents, significant at the $5 \%$ level.

Finally, we observe a reduction in the quantities of monocrotophos and acephate applied, but these differences are not statistically different from zero. We likewise see a reduction in acephate usage of roughly $0.23 \mathrm{~kg}$ among the treatment group, though again this difference is not statistically significant. While the data appears to indicate reductions in the usage of organophosphate pesticides, there is too much noise to conclude that moves to newer pesticides like imidacloprid are being coupled with reductions in the use of older pesticides. We are hopeful that midline data for the entire sample of 1200 respondents will allow us to address these questions with more precision.

\subsection{Sowing Choices}

Table 8 reports the treatment effect on sowing choices for the main winter $(R a b i)$ crops in our sample: cumin and wheat (cotton sowing choices preceded the treatment and are included in Table 1).

We observe that approximately $8 \%$ more treatment group farmers plant cumin relative to control as measured by the first round of the phone survey that concluded in December 2011. Additionally, they also sow a larger quantity of cumin than the control group (nearly $50 \%$ more), significant at the $10 \%$ level. However, using cumulative data from both the 
first and second rounds of the phone survey (the latter concluded in February, 2012) while the point estimate remains large and positive its statistical significance is now attenuated. Two possible reasons for this are that attritors from the treatment group in the second round of the phone survey where $30 \%$ more likely to grow cumin and planted nearly twice as much cumin at baseline relative to attritors from the control group (Table A3). Another interpretation of this result is that treatment farmers were planting cumin earlier in the season, on the basis of weather information provided through push calls suggesting a delayed winter. ${ }^{9}$

This is an important result, as cumin is a high-value cash crop, that requires specialized knowledge to grow. Both the push calls and physical extension services provided substantial information on cumin cultivation. We speculate on possible mechanisms driving these changes in Section 6.

\subsection{Impact on Agricultural Knowledge}

It is important to understand the mechanisms by which $\mathrm{AO}$ works: does it serve as an education tool, creating durable improvements in knowledge, or does it function as an advisory service, in which farmers follow instructions, without necessarily comprehending why a particular course of action is the right one? In Table 9, we examine whether AO improves farmers' ability to answer basic agricultural questions. We ask two sets of questions, one at baseline via paper survey, and a second set in our follow-up phone survey in November. The questions test the respondents on a wide range of topics, which are generally invariant to their personal circumstances. Of course, collecting data by mobile phone limits the types of questions a surveyor can ask, both in terms of their complexity, as difficult questions can be hard to convey over the phone, and their content, as pictures

\footnotetext{
${ }^{9}$ Cumin yields are very sensitive temperature early in the plant cycle and the perception of low temperatures in the future would serve to delay or forego planting.
} 
and other demonstrative materials are not available.

Baseline agricultural knowledge is low, with farmers answering only $29 \%$ of questions correctly. There are no significant differences between treatment and control for the total at the baseline. Given that these are very basic questions about agriculture, this suggests that there is a substantial lack of information on even basic topics concerning crop cultivation.

As reported in Table 9, we do not observe differences between the treatment and control groups in agricultural knowledge (Column 6). In part, the types of knowledge that respondents gain reflect their actual demand for information. The majority of questions asked on the $\mathrm{AO}$ platform relate to pesticides. However, only 2 of 10 questions on the knowledge index are about pest management in cotton; hence the index may be a poor measure of the types of knowledge that farmers have acquired. In future surveying we hope to expand the scope of questions about pest management.

Importantly, we do see a large difference between the AO group and the control group for the question about cumin ("What variety of cumin is recommended for being wiltresistant?"). As we discuss in section 6, this gives some evidence for the mechanism driving the cumin result in the previous section. Importantly, this difference was not present in the baseline: treatment and control farmers had equivalent knowledge of cumin planting.

\subsection{Heterogeneous Treatment Effects}

While the importance of technological progress to growth is beyond doubt, there are growing concerns about the possibility of a "digital divide," in which the poorest or least educated are less able to take full advantage of the promise of new technologies. We test this hypothesis by comparing AO usage and knowledge gain by education level. We focus on respondent education for at least two reasons: first, while the service is designed to be accessible to illiterate users, it may be easier to use or navigate for a literate population, 
who can take advantage of instructional material. Second, educated individuals may be in a better position to learn. (We also examined landholding as a source of heterogeneity in treatment effects, and found virtually no difference between above- and below-median landholders.) The median farmer in our survey reports 4 years of education.

\section{Are AO Usage and Education Complements?}

In Table 10, we regress measures of AO usage on a treatment dummy, a dummy for having more than the median number of years of formal education (4 years), and the corresponding interaction term (columns 1-3).

Column (3) suggests there are some complementarities between AO use and education: more educated farmers make $30 \%$ more calls to the AO line than treatment farmers with lower educational attainment; they are also nearly $8 \%$ more likely to ask a question and listen to more push call information (both significant at the $5 \%$ level).

However, we do not find an effect on the extensive margin; that is, more educated individuals are no more likely to call in to the AO line. This table makes use of administrative data for all 1,200 respondents as their calls (and the absence of calls from control) are logged on to the server.

\section{Sources of Information and Years of Education}

We have also analyzed whether education affects the impact of AO on sources of information. In results available on request, we find large and statistically significant difference in effect size by education. Respondents with above median education in the treatment group cite $\mathrm{AO}$ as their primary source of information for cotton fertilizer and pesticide decisions 12 and 16 percentage points more, respectively. These effects are statistically significant at the $1 \%$ level. Thus, at least at this level, there seems to be some evidence of 
a digital divide, even for an IT product specifically designed to be accessible to illiterate users.

\section{Acquisition of Agricultural Knowledge and Years of Education}

Does this differential use and reliance on AO translate into differential knowledge acquisition? In Table 10, we find a large and statistically significant increase in the treatment effect on the index of agricultural knowledge for respondents with above-median education. The effect for those with below-median education is zero. Educated respondents improve by 4.7 percentage points $(-2.7 \%+7.4 \%)$ overall, and by 18.8 percentage points for cumin-related questions. This provides meaningful evidence that AO-induced learning is considerably greater for the better-educated.

\section{Pesticide Use, Sowing Decisions and Years of Education}

Given the disparities by education in the use of and reported reliance on AO, it is natural to wonder whether we also observe differences in how agricultural practices respond to AO. In tables not reported, we analyze the interaction between $\mathrm{AO}$ and education on pesticide use and sowing decisions. We find no heterogeneous effects. Importantly, the adoption of imidacloprid among AO users, the most immediate and important result in our study, does not appear to vary systematically with years of education. We consider reasons for this association in Section 6 . 


\section{Threats to Validity}

\subsection{Attrition}

Attrition is an important concern, particularly when conducting surveys by telephone, and when the treatment itself involves phone use. Respondents were offered an immediate mobile phone "top-up" of Rs. 20 (one sixth of the central government's daily "minimum wage" for agricultural labor, Rs. 120) upon completion of the phone survey, which lasted from 15-30 minutes and did not cost them airtime. In the first round of the phone survey, we do not find any differential attrition: we reach 369 of the 400 control group (92.25\%), and 368 of the treatment group (92\%). Using data from the baseline paper survey, Appendix Table 4 shows that treatment and control attritees appear to be statistically indistinguishable, based on our standard set of covariates, including age, area of land owned, years of education and crops planted.

In the second round of the phone survey, we had 60 attritees (7.5\%), 31 from the control group and 29 from treatment. On the basis of their baseline characteristics, treatment attritors were more likely to grow wheat and cumin, as well as sow a larger quantity of cumin (See Table A4 ). This suggests that any treatment effect on the probability that a farmer plants cumin is likely an under-estimate.

\subsection{Experimenter Demand Effects}

A second obvious concern is that respondents in the treatment group may offer answers that they believe the research team seeks, perhaps in the hopes of prolonging the research project, or due to a sense of reciprocity. While it is difficult to rule this out entirely, we do note that we can observe some outcomes perfectly: the AO platform records precisely how many times respondents call in. Respondents provide remarkably unbiased answers to the 
question "did you call into the AO line with a question," with 55.5\% self-reported call-in rate vs. a 53.5\% call-in rate using administrative data. We note that the agricultural knowledge effects documented in Tables 9 and 10 are measures of knowledge, rather than self-reported behavior. This concern is particularly important for variables such as "what is your preferred source of agricultural advice?" yet we draw comfort in the fact that relationship between reported reliance on $\mathrm{AO}$ and educational attainment is mirrored in the administrative usage data.

\section{Discussion of Mechanisms}

\subsection{Pesticide Use in Cotton Cultivation}

A discussion of the agronomy of cotton may help shed light on the mechanisms at work. Pest management is one of the most important activities in cotton cultivation. Literally hundreds of pests afflict cotton, and cotton farming accounts for $54 \%$ of all pesticide usage in India (but only $5 \%$ of land under cultivation, Foundation (2007)). From piloting AO and previous work (Patel, Chittamuru, Jain, Dave, and Parikh (2010)), it was clear that AO respondents would seek information on pesticide usage and pest identification. Four months after rolling out the intervention, pest management accounts for $59 \%$ of all questions on $\mathrm{AO}$ and $73 \%$ of questions asked about cotton (See Table 3).

Importantly, cotton is afflicted by two classes of pests: known as the "Boll worm complex" and "sucking pests." Roughly $95 \%$ of our sample use Bt cotton that offers immunity to the "Boll worm complex," and would therefore largely not benefit from many pesticides needed to treat boll worms. However, only $45 \%$ of the entire sample (with no appreciable differences across the treatment cells) appear to know this fact (this was one of the questions in the agricultural knowledge survey). Approximately $94 \%$ of our respondents 
say they have experienced a sucking pest attack, while in contrast, just $12 \%$ say they have experienced a boll worm attack (Table A2). Seasonal variation in both the types of pests and the resistance they develop to varieties of cotton and pesticides put a premium on timely information for pest control. ${ }^{10}$ As a result, effective pest control both in terms of the types of pesticides used and the quantity applied is the subject of constant learning and therefore not a well-established, settled process.

Indeed, while a majority of pesticide use is accounted for by monocrotophos and acephate, these pesticides are largely intended to deal with the aforementioned "boll worm complex," and therefore newer neonicotinoid pesticides like imidaclorprid and acetamiprid are more effective in dealing with the most frequent sucking pest attacks: jassids, aphids and mealy bug (See Appendix Table A2 ), by directly targeting their nervous systems.

Qualitative work conducted by the authors suggests that farmers continue to use monocrotophos because they believe it to be effective against all pests. They have limited awareness about alternatives and (incorrectly) value the sheen left by the pesticide, which they refer to as kunap, which translates to "greenery." Without access to quality agricultural information services, farmeres rely on input dealers for recommendations on pesticide use. Because the cost of not applying enough pesticide may be very high, we expect that in an environment of uncertainty and limited access to quality, unbiased advice, farmers may overuse pesticides.

\subsection{Changes in Pesticide Use: Learning or Imitation}

We observe large shifts in the number of treatment farmers reporting that they consider AO their main source of information in making agricultural decisions for cotton, cumin and wheat. In addition, we also observe them shifting away from input dealerships and other

\footnotetext{
${ }^{10}$ One caveat to this dichotomy is that Monsanto recently acknowledged that its first generation Bt crop, Bollguard I, is now ineffective against pink boll worm in Gujarat (Jebaraj (2010))
} 
farmers, which are the dominant sources of information. Importantly, we observe both an increase in the number of treatment farmers buying and using imidacloprid and reduction in the amount spent on monocrotophos and acephate, and in the amounts. Both these effects would seem to suggest that farmers are internalizing the information being provided by $\mathrm{AO}$ about the inefficacy of organophosphate pesticides and the need to use pesticides that specifically target sucking pests.

The knowledge index was kept concise to facilitate administration via a phone survey, so our ability to detect whether or not farmers have internalized the information provided by $\mathrm{AO}$ is limited. Two questions on the index are related to pesticide use in cotton; the question about white-fly (Q4) is largely orthogonal to the discussion about monocrotophos and imidacloprid, as the pesticide prescribed for use against white fly is acetamaprid. However, if we are to posit a learning story, it is perhaps surprising that more treatment farmers are not able to answer correctly Q2, which asks what class of pests Bt cotton provides resistance against. Indeed, we observe that more educated farmers do seem to have internalized this information (results not reported), but observed changes in pesticide use do not vary with education.

This does not provide strong evidence that farmers in the treatment group are using and purchasing less organophosphates because they learn that Bt cotton is largely immune to the pests they target. However, this does not rule out a learning story, since it may well be that respondents have simply updated their belief about which pesticides are more effective against sucking pests, regardless of complementarities with Bt cotton. Future work will seek to vary treatment information to help distinguish between learning and imitation, though such disentanglement may be difficult.

In the case of farmers planting cumin, we observe that treatment farmers are far more likely $(12 \%)$ to know the recommended variety of wilt-resistant cumin. Cumin is partic- 
ularly sensitive to weather and wilt is the major disease that afflicts it, so it is indeed plausible that treatment farmers armed with this new information are more comfortable planting large amounts of cumin.

\section{Conclusion}

This paper presents the results from a randomized experiment studying the impact of providing toll-free access to AO, a mobile phone-based technology that allows farmers to receive timely agricultural information from expert agronomists and their peers.

Firstly, we show that the intervention was successful in generating a substantial amount of $\mathrm{AO}$ usage, with roughly $60 \%$ of the treatment group calling in to listen to content or ask a question within 7 months of beginning the intervention. We then showed that AO had

a large impact on reported sources of information used in agricultural decisions, reducing the reliance of treatment respondents on input dealers and other farmers for advice on pest management. We separately show that these effects are increasing in the years of education of the respondents.

While at first glance we do not observe a dramatic impact of AO on agricultural knowledge, this finding appears to mask substantial heterogeneity between respondents with above and below-median education. These results, combined with results showing that more educated farmers use AO more, suggests the presence of a digital divide.

Having established $\mathrm{AO}$ as a reliable source of information, we then show that advice provided through AO resulted in farmers purchasing and applying a more effective pesticide, imidacloprid, to treat sucking pests. In addition we observe reduced expenditure on older, less effective pesticides, and reduced usage although these coefficients are not estimated with enough precision to distinguish them from zero. Treatment farmers plant substantially more cumin than control farmers. 
While we cannot yet estimate the value to the households of these changed agricultural practices, and hence cannot compute a cost-benefit analysis, we do note that the cost of this intervention is quite low: we estimate a monthly cost of approximately USD $\$ 1.13$ per farmer (including all airtime costs, staff time, and technology fees) if the project were implemented at scale (a single agronomist can handle approximately 2,000 farmers). In contrast, the "all-in" costs for physical extension were about $\$ 8.50$ per farmer.

Of course, as the scale of AO grows, the costs may drop dramatically, as pre-recorded answers to specific questions dramatically reduce the amount of time the agronomists must spend on each question. We provided free airtime to farmers in an attempt to obtain high take-up; if this cost (ca. \$.60) were shifted to the farmer, the service would have to charge only $\$ .53 /$ month to farmers to break even. If we see sustained increases in imidacloprid, and reductions in monocrotophos, this effect alone may ensure the service is cost-effectivethough it remains to be seen whether farmers would be willing to pay for the advice.

These results represent the beginning of a research agenda seeking to understand the importance of information and management in small farmer agriculture. Many important questions remain unanswered. Because we recorded the names of each respondent's closest contacts prior to treatment assignment, we will be able to precisely measure spillovers of information by comparing contacts of treatment farmers to control farmers. Going forward, the individual nature of delivery and information access (each farmer can potentially receive a different push call message, and each can choose which other reported experiences to listen to) will allow us to test the importance of top-down vs. bottom-up information.

One of the features of the current intervention is that the NGO providing the service, DSC, has established trust by providing services to farmers for many years. While certain aspects of observed input adoption like pesticide use allow for sequential learning, for large investments where the downside risk could be potentially devastating, as in the case 
of cumin sowing, trust would appear to be a lot more important. AO comes across as a service without a vested interest (impartial) in addition to being experts, which may well serve to both encourage farmers to switch away from other sources and act on AO information. We hope to experimentally vary the source of information (if only to present it as a peer instead of an expert) in order to understand the importance of this aspect for technology adoption.

To understand the exact mechanism through which AO affects behavior, it is also important to understand whether the treatment effect is working through acquired knowledge or "merely" persuasion. One definition of cognitive persuasion that has been adopted in the literature is that it consists of "tapping in to already prevailing mental models and beliefs" through associations rather than teaching or inculcating the subject with new information. From qualitative work we have conducted, many farmers claim to distrust input dealerships but still adopt their advice for lack of a better source. While this is not something that is emphasized in the AO service itself, the presentation of information that seems to conflict with the advice given by input merchants may well serve to reinforce this distrust. We hope to be able to test these hypotheses using pre- and post- subjective evaluations of the trustworthiness of information sources. However, a more elaborate treatment play may be necessary to clearly distinguish between the two models of how information affects behavior.

Finally, we stress the practical importance of this technology. Climate change and the mono-cropping of new varieties of cotton may significantly alter both the types and frequency of pests, and the effectiveness of pesticides in the near future. Farmers in isolated rural areas have little recourse to scientific information that might allow them to adapt to these contingencies. We believe mobile phone-based agricultural extension presents a cost-effective and salient conduit through which to relay such information. 


\section{References}

Aker, J. (2011): "Dial "A" for Agriculture: Using ICT's for Agricultural Extension in Development Countries," Agricultural Economics. 2.2

Anderson, J., And R. Birner (2007): "How to Make Agricultural Extension DemandDriven? : The Case of India's Agricultural Extension Policy," IFPRI Discussion Paper 00729. 2.1

Anderson, K., And G. Feder (2007): "Chapter 44: Agricultural Extension," Handbook of Agricultural Economics. 2.1

Bardhan, P., And D. MookherJee (2011): "Subsidized Farm Input Programs and Agricultural Performance: A Farm-Level Analysis of West Bengal's Green Revolution, 1982-1995," American Economic Journal: Applied Economics, 3(4). 1

Birkhaeuser, D., R. Evenson, And G. Feder (1991): "The Economic Impact of Agricultural Extension: A Review," Economic Development and Cultural Change. 1, 2.1

Duflo, E., M. Kremer, and J. Robinson (2011): "How High are Rates of Return to Fertilizer? Evidence from Field Experiments in Kenya," Nudging Farmers to USe Fertilizer: Theory and Experimental Evidence in Kenya. 1

FEDER, G. (2005): "The challenges facing agricultural extension - and a new opportunity," New Agriculturalist. 2.1

Feder, G., L. Lau, and R. Slade (1987): "Does Agricultural Extension Pay? The Training and Visit System in Northwest India," American Journal of Agricultural Economics, 69(3). 1 
Foster, A., And M. Rosenzweig (2010): "Microeconomics of Technology Adoption," Annual Reviews of Economics. 1

Foundation, E. J. (2007): "The Deadly Chemicals in Cotton," . 6.1

Gandhi, R., R. Veeraraghavan, K. Toyama, and V. Ramprasad (2009): "Digital Green: Participatory Video and Instruction for Agricultural Extension," Information Technologies and International Development, 5(1). 1

Glendenning, C., S. Babu, and K. Asenso-Okyere (2010): "Review of Agricultural Extension in India: Are Farmer' Information Needs Being Met?," IFPRI Discussion Paper 01048. 2.1

JACK, K. (2011): "Market Inefficiences and the Adoption of Agricultural Technologies in Developing Countries," ATAI. 1, 3

JebaraJ, P. (2010): "Bt cotton ineffective against pest in parts of Gujarat, admits Monsanto," . 10

McKenzie, D., And C. Woodruff (2012): "What are we learning from business training and entrepreneurship evaluations around the developing world?," World Bank Policy Research Working Paper, (6202). 1

Patel, N., D. Chittamuru, A. Jain, P. Dave, and T. Parikh (2010): “Avaaj Otalo - A Field Study of an Interactive Voice Forum for Small Farmers in Rural India," Proceedings of ACM Conference on Human Factors in Computing Systems. 2.2, 6.1

Saito, K., and C. Weidemann (1990): "Agricultural Extension for Women Farmers in Africa," World Bank. 2.1 


\section{Appendix}

\section{Knowledge Index Questions}

The following are the knowledge index questions used to gauge agricultural knowledge. The analysis of this index is presented in Table 7 (see below). All these questions have a 'right answer', in that they do not depend on the individual circumstances faced by farmers. Where there are other factors (e.g. prices) that might influence the answer, this is generally worked in to the question (e.g. Q4) to negate its influence in delivering subjective responses to the extent possible without overly complicating the question.

Q1: In cotton, how many times should nitrogen or urea be applied?

Q2: Which class of pests is Bt cotton is resistant to?

Q3: Which essential nutrient does urea contain?

Q4: If money were not a constraint, best pesticide for cotton white-fly?

Q5: How does leaf curl in cotton spread?

Q6: In case of yellowing of cotton, which fertilizer is advised to spray?

Q7: How much urea fertilizer should be applied to cotton as a split application?

Q8: Which fertilizer should spray in case of falling of flowers and buds in cotton?

Q9: Which fungicide should be applied to control wilt in cotton?

Q10: Which wilt resistant variety of cumin is recommended? 
Table 1-Summary Statistics by Treatment Status

\begin{tabular}{|c|c|c|c|c|c|c|}
\hline Cell contents: & $\begin{array}{c}\text { Control Group } \\
\text { Mean } \\
(1) \\
\end{array}$ & $\begin{array}{l}\text { AO Only } \\
\text { Mean } \\
(2)\end{array}$ & $\begin{array}{c}\mathrm{AO}+\text { Extension } \\
\text { Mean } \\
(3) \\
\end{array}$ & $\begin{array}{c}\text { AO-Control } \\
\text { ITT } \\
(4) \\
\end{array}$ & $\begin{array}{c}\text { AOE-Control } \\
\text { ITT } \\
(5) \\
\end{array}$ & $\begin{array}{c}\text { Treat-Control } \\
\text { ITT } \\
(6) \\
\end{array}$ \\
\hline \multicolumn{7}{|l|}{ A. Sample Size } \\
\hline Entire Sample & 398 & 399 & 403 & 797 & 801 & 1200 \\
\hline Subset in Phone Survey & 398 & 200 & 200 & 200 & 200 & 798 \\
\hline \multicolumn{7}{|l|}{ B. Individual Characteristics } \\
\hline Age & $\begin{array}{c}35.77 \\
(10.22)\end{array}$ & $\begin{array}{c}36.85 \\
(10.81)\end{array}$ & $\begin{array}{c}35.64 \\
(10.50)\end{array}$ & $\begin{array}{l}1.09 \\
(0.75)\end{array}$ & $\begin{array}{l}-0.12 \\
(0.73)\end{array}$ & $\begin{array}{l}0.48 \\
(0.64)\end{array}$ \\
\hline Years of Education & $\begin{array}{l}4.21 \\
(3.84)\end{array}$ & $\begin{array}{l}3.97 \\
(3.97)\end{array}$ & $\begin{array}{l}4.09 \\
(3.90)\end{array}$ & $\begin{array}{l}-0.25 \\
(0.28)\end{array}$ & $\begin{array}{l}-0.12 \\
(0.27)\end{array}$ & $\begin{array}{l}-0.19 \\
(0.24)\end{array}$ \\
\hline Landholdings - Acres & $\begin{array}{c}6.69 \\
(16.22)\end{array}$ & $\begin{array}{l}5.66 \\
(4.94)\end{array}$ & $\begin{array}{l}6.08 \\
(5.61)\end{array}$ & $\begin{array}{l}-1.03 \\
(0.85)\end{array}$ & $\begin{array}{l}-0.62 \\
(0.86)\end{array}$ & $\begin{array}{l}-0.82 \\
(0.83)\end{array}$ \\
\hline Agricultural Income ('000s) & $\begin{array}{c}162.5 \\
(146.7)\end{array}$ & $\begin{array}{c}169.5 \\
(161.7)\end{array}$ & $\begin{array}{c}167.2 \\
(166.3)\end{array}$ & $\begin{array}{c}6.9 \\
(11.0)\end{array}$ & $\begin{array}{c}4.6 \\
(11.1)\end{array}$ & $\begin{array}{c}5.8 \\
(9.4)\end{array}$ \\
\hline \multicolumn{7}{|c|}{ C. Historic Agricultural Activity } \\
\hline Planted Cotton, 2010 & $\begin{array}{c}0.98 \\
(0.12)\end{array}$ & $\begin{array}{l}0.98 \\
(0.15)\end{array}$ & $\begin{array}{l}0.99 \\
(0.11)\end{array}$ & $\begin{array}{l}-0.01 \\
(0.01)\end{array}$ & $\begin{array}{l}0.00 \\
(0.01)\end{array}$ & $\begin{array}{l}0.00 \\
(0.01)\end{array}$ \\
\hline Area Cotton Planted, 2010 & $\begin{array}{l}4.45 \\
(3.62)\end{array}$ & $\begin{array}{l}5.01 \\
(4.05)\end{array}$ & $\begin{array}{l}4.74 \\
(4.43)\end{array}$ & $\begin{array}{c}0.57 * * \\
(0.27)\end{array}$ & $\begin{array}{l}0.29 \\
(0.29)\end{array}$ & $\begin{array}{l}0.43 * \\
(0.24)\end{array}$ \\
\hline Planted Cotton, 2011 & $\begin{array}{c}0.98 \\
(0.15)\end{array}$ & $\begin{array}{c}0.97 \\
(0.16)\end{array}$ & $\begin{array}{c}1.00 \\
(0.00)\end{array}$ & $\begin{array}{l}-0.01 \\
(0.01)\end{array}$ & $\begin{array}{c}0.02 * * * \\
(0.01)\end{array}$ & $\begin{array}{c}0.01 \\
(0.01)\end{array}$ \\
\hline Area Cotton Planted, 2011 & 4.99 & 5.59 & 5.21 & 0.60 & 0.22 & 0.41 \\
\hline Planted Wheat, 2010 & $\begin{array}{l}(4.35) \\
0.78 \\
(0.42)\end{array}$ & $\begin{array}{l}(4.32) \\
0.72 \\
(0.45)\end{array}$ & $\begin{array}{l}(3.54) \\
0.72 \\
(0.45)\end{array}$ & $\begin{array}{l}(0.39) \\
-0.05^{*} \\
(0.03)\end{array}$ & $\begin{array}{l}(0.35) \\
-0.05 \\
(0.03)\end{array}$ & $\begin{array}{c}(0.31) \\
-0.05 * * \\
(0.03)\end{array}$ \\
\hline Area Wheat Planted, 2010 & $\begin{array}{l}1.17 \\
(1.35)\end{array}$ & $\begin{array}{l}1.35 \\
(2.30)\end{array}$ & $\begin{array}{c}1.07 \\
(1.25)\end{array}$ & $\begin{array}{l}0.18 \\
(0.13)\end{array}$ & $\begin{array}{l}-0.10 \\
(0.09)\end{array}$ & $\begin{array}{l}0.04 \\
(0.09)\end{array}$ \\
\hline Planted Cumin, 2010 & $\begin{array}{c}0.42 \\
(0.49)\end{array}$ & $\begin{array}{l}0.40 \\
(0.49)\end{array}$ & $\begin{array}{c}0.41 \\
(0.49)\end{array}$ & $\begin{array}{l}-0.02 \\
(0.03)\end{array}$ & $\begin{array}{l}-0.01 \\
(0.03)\end{array}$ & $\begin{array}{l}-0.02 \\
(0.03)\end{array}$ \\
\hline Area Cumin Planted, 2010 & $\begin{array}{l}0.76 \\
(1.41)\end{array}$ & $\begin{array}{c}0.79 \\
(1.50)\end{array}$ & $\begin{array}{l}0.70 \\
(1.34)\end{array}$ & $\begin{array}{l}0.03 \\
(0.10)\end{array}$ & $\begin{array}{l}-0.06 \\
(0.10)\end{array}$ & $\begin{array}{l}-0.02 \\
(0.09)\end{array}$ \\
\hline
\end{tabular}

Notes:Estimates presented are for the entire sample. The subset of the sample surveyed by phone is also reported as subsequent treatment effects rely on this sample (See Panel A). We conducted a baseline survey for study participants between June 26 and August 11, 2011. Participants were randomized into three groups. AO group received AO access. AOE group received both AO and physical extension. 'Treat' refers to the combined treatment group in the phone survey. The control Group received neither treatment. Columns 1-3 provide the mean and standard deviation by treatment status. Columns 4-6 report an Intention to Treat (ITT) estimate of the difference in means (and the robust standard error) between the treatment groups and the control group. ${ }^{* * *}$ significant at $1 \%$ level; $* *$ significant at $5 \%$ level; $*$ significant at $10 \%$ level. 
Table 2-Baseline Sources for Information for Agricultural Decision Making

\begin{tabular}{|c|c|c|c|c|c|c|c|c|c|c|}
\hline \multirow[b]{3}{*}{ Cell contents: } & \multicolumn{2}{|c|}{ Cotton Planting } & \multicolumn{2}{|c|}{ Cotton Fertilizer } & \multicolumn{2}{|c|}{ Cotton Pesticide } & \multicolumn{2}{|c|}{ Wheat Planting } & \multicolumn{2}{|c|}{ Cumin Planting } \\
\hline & Control & Treat - Control & Control & Treat - Control & Control & Treat - Control & Control & Treat - Control & Control & Treat - Control \\
\hline & $\begin{array}{c}\text { Mean } \\
\text { (1) }\end{array}$ & $\begin{array}{c}\text { ITT } \\
(2)\end{array}$ & $\begin{array}{c}\text { Mean } \\
\text { (3) }\end{array}$ & $\begin{array}{c}\text { ITT } \\
(4)\end{array}$ & $\begin{array}{c}\text { Mean } \\
(5)\end{array}$ & $\begin{array}{c}\text { ITT } \\
(6)\end{array}$ & $\begin{array}{l}\text { Mean } \\
\text { (7) }\end{array}$ & $\begin{array}{c}\text { ITT } \\
(8)\end{array}$ & $\begin{array}{c}\text { Mean } \\
(9)\end{array}$ & $\begin{array}{l}\text { ITT } \\
(10)\end{array}$ \\
\hline Asked for or received advice & $\begin{array}{c}0.324 \\
(0.469)\end{array}$ & $\begin{array}{c}0.016 \\
(0.029)\end{array}$ & $\begin{array}{c}0.265 \\
(0.442)\end{array}$ & $\begin{array}{l}-0.005 \\
(0.027)\end{array}$ & $\begin{array}{c}0.594 \\
(0.492)\end{array}$ & $\begin{array}{c}0.035 \\
(0.030)\end{array}$ & $\begin{array}{c}0.138 \\
(0.346)\end{array}$ & $\begin{array}{l}-0.004 \\
(0.021)\end{array}$ & $\begin{array}{c}0.131 \\
(0.337)\end{array}$ & $\begin{array}{l}-0.022 \\
(0.020)\end{array}$ \\
\hline Importance of source consulte & & & & & & & & & & \\
\hline Past experience & $\begin{array}{c}0.015 \\
(0.122)\end{array}$ & $\begin{array}{l}-0.003 \\
(0.007)\end{array}$ & $\begin{array}{c}0.013 \\
(0.112)\end{array}$ & $\begin{array}{l}-0.004 \\
(0.006)\end{array}$ & $\begin{array}{c}0.018 \\
(0.132)\end{array}$ & $\begin{array}{l}-0.009 \\
(0.007)\end{array}$ & $\begin{array}{c}0.005 \\
(0.071)\end{array}$ & $\begin{array}{c}0.002 \\
(0.005)\end{array}$ & $\begin{array}{l}- \\
-\end{array}$ & - \\
\hline TV program & $\begin{array}{c}0.003 \\
(0.050)\end{array}$ & $\begin{array}{c}0.000 \\
(0.003)\end{array}$ & $\begin{array}{c}0.005 \\
(0.071)\end{array}$ & $\begin{array}{l}-0.003 \\
(0.004)\end{array}$ & $\begin{array}{c}0.005 \\
(0.071)\end{array}$ & $\begin{array}{l}-0.001 \\
(0.004)\end{array}$ & - & - & $\begin{array}{c}0.003 \\
(0.050)\end{array}$ & $\begin{array}{l}-0.003 \\
(0.003)\end{array}$ \\
\hline Mobile phone-based & - & - & $\begin{array}{c}0.003 \\
(0.050)\end{array}$ & $\begin{array}{c}-0.003 \\
(0.003)\end{array}$ & - & - & - & - & $\begin{array}{c}0.000 \\
(0.000)\end{array}$ & $\begin{array}{c}0.000 \\
(0.000)\end{array}$ \\
\hline Gov't extension & - & - & $\begin{array}{c}0.003 \\
(0.050)\end{array}$ & $\begin{array}{c}-0.003 \\
(0.003)\end{array}$ & $\begin{array}{c}0.003 \\
(0.050)\end{array}$ & $\begin{array}{c}0.001 \\
(0.003)\end{array}$ & - & - & $\begin{array}{c}0.003 \\
(0.050)\end{array}$ & $\begin{array}{c}-0.003 \\
(0.003)\end{array}$ \\
\hline NGO & $\begin{array}{c}0.005 \\
(0.071)\end{array}$ & $\begin{array}{c}-0.004 \\
(0.004)\end{array}$ & $\begin{array}{c}0.005 \\
(0.071)\end{array}$ & $\begin{array}{c}-0.004 \\
(0.004)\end{array}$ & $\begin{array}{c}0.003 \\
(0.050)\end{array}$ & $\begin{array}{c}0.001 \\
(0.003)\end{array}$ & - & - & $\begin{array}{c}0.000 \\
(0.000)\end{array}$ & $\begin{array}{c}0.001 \\
(0.001)\end{array}$ \\
\hline Other farmers & $\begin{array}{c}0.266 \\
(0.443)\end{array}$ & $\begin{array}{c}0.013 \\
(0.027)\end{array}$ & $\begin{array}{c}0.191 \\
(0.394)\end{array}$ & $\begin{array}{c}-0.006 \\
(0.024)\end{array}$ & $\begin{array}{c}0.246 \\
(0.431)\end{array}$ & $\begin{array}{c}0.011 \\
(0.027)\end{array}$ & $\begin{array}{c}0.108 \\
(0.311)\end{array}$ & $\begin{array}{c}-0.006 \\
(0.019)\end{array}$ & $\begin{array}{c}0.083 \\
(0.276)\end{array}$ & $\begin{array}{c}-0.003 \\
(0.017)\end{array}$ \\
\hline Input shops & $\begin{array}{c}0.025 \\
(0.157)\end{array}$ & $\begin{array}{c}0.010 \\
(0.010)\end{array}$ & $\begin{array}{c}0.038 \\
(0.191)\end{array}$ & $\begin{array}{c}0.006 \\
(0.012)\end{array}$ & $\begin{array}{c}0.302 \\
(0.459)\end{array}$ & $\begin{array}{c}0.029 \\
(0.028)\end{array}$ & $\begin{array}{c}0.015 \\
(0.122)\end{array}$ & $\begin{array}{c}0.001 \\
(0.008)\end{array}$ & $\begin{array}{c}0.035 \\
(0.184)\end{array}$ & $\begin{array}{c}-0.013 \\
(0.011)\end{array}$ \\
\hline $\mathrm{N}$ & 398 & 1200 & 398 & 1200 & 398 & 1200 & 398 & 1200 & 398 & 1200 \\
\hline
\end{tabular}

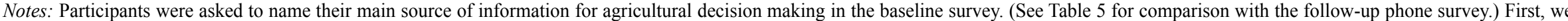

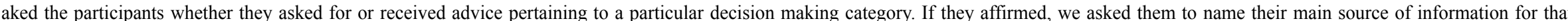

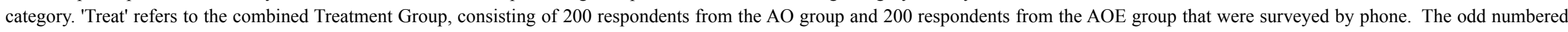

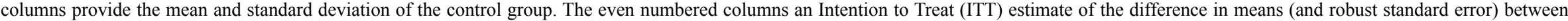
the treatment groups and the control group. ${ }^{* *}$ significant at $1 \%$ level; $* *$ significant at $5 \%$ level; * significant at $10 \%$ level. 
Table 3-Topics of Questions Asked and Push Calls

\begin{tabular}{lcccc}
\hline & $\begin{array}{c}\text { No. of Questions asked } \\
(1)\end{array}$ & $\begin{array}{c}\text { \% of Total Asked } \\
(2)\end{array}$ & $\begin{array}{c}\text { No. of Push Calls } \\
(3)\end{array}$ & $\begin{array}{c}\text { \% of Push Calls } \\
(4)\end{array}$ \\
$\begin{array}{l}\text { A. Question Count by Crop } \\
\text { Cotton }\end{array}$ & 739 & 0.67 & 12 & 0.38 \\
Cumin & 62 & 0.06 & 15 & 0.47 \\
Wheat & 19 & 0.02 & 9 & 0.28 \\
$\begin{array}{l}\text { B. Question Count by Theme } \\
\text { Pest mangagement }\end{array}$ & 690 & & 22 & 0.69 \\
Cotton pest management & 542 & 0.63 & 8 & 0.25 \\
Fertilizers & 90 & 0.49 & 17 & 0.53 \\
Seeds & 67 & 0.08 & 4 & 0.13 \\
Other & 301 & 0.06 & - & - \\
Total & 1104 & 0.27 & 32 & 1.00 \\
\hline
\end{tabular}

Notes:Questions asked on AO prior to the second round of the phone survey are categorized by their related crops and themes. All Push calls contain information on multiple themes. The numbers include those questions asked by respondents who were assigned to receive $\mathrm{AO}$ access but were not included in the phone survey sample. A total of 32 push calls were sent during August 2011 - March 2012, with the average length of a push call at approximately 5 minutes. 
Table 4-Summary Statistics by AO Usage

\begin{tabular}{|c|c|c|c|c|c|}
\hline Cell contents: & $\begin{array}{r}\text { Control } \\
\text { Mean } \\
(1) \\
\end{array}$ & $\begin{array}{c}\text { Treat - Control } \\
\text { ITT } \\
(2)\end{array}$ & & $\begin{array}{c}\text { Treat - Control } \\
\text { ITT } \\
(3) \\
\end{array}$ & \\
\hline Called AO line & $\begin{array}{r}0.005 \\
(0.071)\end{array}$ & $\begin{array}{c}0.586 \\
(0.018)\end{array}$ & $* * *$ & $\begin{array}{c}0.587 \\
(0.025)\end{array}$ & $* * *$ \\
\hline $\begin{array}{l}\text { Total Incoming AO usage } \\
\text { Minutes }\end{array}$ & $\begin{array}{r}0.005 \\
(0.077)\end{array}$ & $\begin{array}{l}91.569 \\
(9.855)\end{array}$ & $* * *$ & $\begin{array}{l}103.202 \\
(15.135)\end{array}$ & $* * *$ \\
\hline Number of calls made & $\begin{array}{r}0.005 \\
(0.071)\end{array}$ & $\begin{array}{c}6.714 \\
(0.786)\end{array}$ & $* * *$ & $\begin{array}{c}7.560 \\
(1.397)\end{array}$ & $* * *$ \\
\hline $\begin{array}{l}\text { Average call time } \\
\text { Minutes }\end{array}$ & $\begin{array}{r}0.005 \\
(0.077)\end{array}$ & $\begin{array}{c}6.240 \\
(0.354)\end{array}$ & $* * *$ & $\begin{array}{c}6.424 \\
(0.496)\end{array}$ & $* * *$ \\
\hline Asked a Question & $\begin{array}{r}0.003 \\
(0.050)\end{array}$ & $\begin{array}{c}0.305 \\
(0.017)\end{array}$ & $* * *$ & $\begin{array}{c}0.322 \\
(0.024)\end{array}$ & $* * *$ \\
\hline Number of questions asked & $\begin{array}{r}0.005 \\
(0.100)\end{array}$ & $\begin{array}{c}1.524 \\
(0.156)\end{array}$ & $* * *$ & $\begin{array}{c}1.720 \\
(0.251)\end{array}$ & $* * *$ \\
\hline Responded to Question & $\begin{array}{r}0.000 \\
(0.000)\end{array}$ & $\begin{array}{c}0.150 \\
(0.013)\end{array}$ & $* * *$ & $\begin{array}{c}0.168 \\
(0.019)\end{array}$ & $* * *$ \\
\hline Number of responses & $\begin{array}{r}0.000 \\
(0.000)\end{array}$ & $\begin{array}{c}0.428 \\
(0.058)\end{array}$ & $* * *$ & $\begin{array}{c}0.493 \\
(0.088)\end{array}$ & $* * *$ \\
\hline $\begin{array}{l}\text { Percentage of Total Push Call } \\
\text { time Listened to }\end{array}$ & $\begin{array}{r}0.000 \\
(0.000)\end{array}$ & $\begin{array}{c}0.655 \\
(0.011)\end{array}$ & $* * *$ & $\begin{array}{c}0.654 \\
(0.016)\end{array}$ & $* * *$ \\
\hline $\begin{array}{l}\text { Listened to at least } 10 \% \text { of } \\
\text { Push call content }\end{array}$ & $\begin{array}{r}0.000 \\
(0.000)\end{array}$ & $\begin{array}{c}0.948 \\
(0.008)\end{array}$ & $* * *$ & $\begin{array}{c}0.938 \\
(0.012)\end{array}$ & $* * *$ \\
\hline Sample & I Control & $\begin{array}{l}\text { All Control }+ \\
\text { All Treat }\end{array}$ & & $\begin{array}{c}\text { All Control + } \\
\text { Phone Survey } \\
\text { Treat }\end{array}$ & \\
\hline $\mathrm{N}$ & 398 & 1200 & & 798 & \\
\hline
\end{tabular}

Notes:Usage statistics were collected on the AO server. 'Treat' refers to the combined Treatment Group, consisting of 200 respondents from the AO group and 200 respondents from the AOE group that were surveyed by phone The. AO group received $\mathrm{AO}$ access. The $\mathrm{AOE}$ group received both $\mathrm{AO}$ and physical extension. Column 1 provides the mean and standard deviation of the control group. Columns 2-3 provide an Intention to Treat (ITT) estimate of the difference in means (and the robust standard error) between the treatment group and the control group. ${ }^{* *}$ significant at $1 \%$ level; $* *$ significant at $5 \%$ level; * significant at $10 \%$ level. 
Table 5-Importance of Information Sources for Agricultural Decision Making

\begin{tabular}{|c|c|c|c|c|c|c|c|c|c|c|}
\hline \multirow[b]{3}{*}{ Cell contents: } & \multicolumn{2}{|c|}{ Cotton Planting } & \multicolumn{2}{|c|}{ Cotton Fertilizer } & \multicolumn{2}{|c|}{ Cotton Pesticide } & \multicolumn{2}{|c|}{ Wheat Planting } & \multicolumn{2}{|c|}{ Cumin Planting } \\
\hline & Control & Treat-Control & Control & Treat-Control & Control & Treat-Control & Control & Treat-Control & Control & Treat-Control \\
\hline & $\begin{array}{c}\text { Mean } \\
(1) \\
\end{array}$ & $\begin{array}{c}\text { ITT } \\
(2) \\
\end{array}$ & $\begin{array}{c}\text { Mean } \\
(3)\end{array}$ & $\begin{array}{c}\text { ITT } \\
(4) \\
\end{array}$ & $\begin{array}{c}\text { Mean } \\
(5)\end{array}$ & $\begin{array}{r}\text { ITT } \\
(6) \\
\end{array}$ & $\begin{array}{c}\text { Mean } \\
(7) \\
\end{array}$ & $\begin{array}{r}\text { ITT } \\
(8) \\
\end{array}$ & $\begin{array}{c}\text { Mean } \\
(9) \\
\end{array}$ & $\begin{array}{l}\text { ITT } \\
(10) \\
\end{array}$ \\
\hline \multicolumn{11}{|c|}{ Importance of source consulted } \\
\hline Past experience & $\begin{array}{c}0.612 \\
(0.488)\end{array}$ & $\begin{array}{c}0.078 * * \\
(0.035)\end{array}$ & $\begin{array}{c}0.496 \\
(0.501)\end{array}$ & $\begin{array}{c}0.029 \\
(0.037)\end{array}$ & $\begin{array}{c}0.291 \\
(0.455)\end{array}$ & $\begin{array}{l}-0.018 \\
(0.033)\end{array}$ & $\begin{array}{l}0.138 \\
(0.346)\end{array}$ & $\begin{array}{c}-0.040^{*} \\
(0.024)\end{array}$ & $\begin{array}{c}0.179 \\
(0.384)\end{array}$ & $\begin{array}{l}-0.035 \\
(0.027)\end{array}$ \\
\hline TV program & $\begin{array}{c}0.008 \\
(0.090)\end{array}$ & $\begin{array}{l}-0.005 \\
(0.005)\end{array}$ & $\begin{array}{c}0.011 \\
(0.104)\end{array}$ & $\begin{array}{l}0.000 \\
(0.008)\end{array}$ & $\begin{array}{c}0.003 \\
(0.053)\end{array}$ & $\begin{array}{l}0.003 \\
(0.005)\end{array}$ & 0 & $\begin{array}{l}0.003 \\
(0.003)\end{array}$ & $\begin{array}{c}0.003 \\
(0.052)\end{array}$ & $\begin{array}{l}0.000 \\
(0.004)\end{array}$ \\
\hline Mobile phone-based & $\begin{array}{l}0.003 \\
(0.052)\end{array}$ & $\begin{array}{c}0.087 * * * \\
(0.015)\end{array}$ & $\begin{array}{c}0.003 \\
(0.052)\end{array}$ & $\begin{array}{c}0.223 * * * \\
(0.022)\end{array}$ & $\begin{array}{c}0.006 \\
(0.074)\end{array}$ & $\begin{array}{c}0.297 * * * \\
(0.024)\end{array}$ & 0 & $\begin{array}{c}0.052 * * * \\
(0.012)\end{array}$ & 0 & $\begin{array}{c}0.125 * * * \\
(0.017)\end{array}$ \\
\hline Gov't extension & $\begin{array}{c}0.008 \\
(0.090)\end{array}$ & $\begin{array}{l}-0.003 \\
(0.006)\end{array}$ & $\begin{array}{c}0.011 \\
(0.104)\end{array}$ & $\begin{array}{c}0.005 \\
(0.009)\end{array}$ & $\begin{array}{c}0.008 \\
(0.091)\end{array}$ & $\begin{array}{c}0.003 \\
(0.007)\end{array}$ & 0 & 0 & $\begin{array}{c}0.005 \\
(0.074)\end{array}$ & $\begin{array}{l}-0.005 \\
(0.004)\end{array}$ \\
\hline NGO & $\begin{array}{c}0.043 \\
(0.204)\end{array}$ & $\begin{array}{l}-0.008 \\
(0.014)\end{array}$ & $\begin{array}{c}0.051 \\
(0.221)\end{array}$ & $\begin{array}{l}-0.013 \\
(0.015)\end{array}$ & $\begin{array}{c}0.044 \\
(0.206)\end{array}$ & $\begin{array}{l}-0.011 \\
(0.014)\end{array}$ & $\begin{array}{l}0.014 \\
(0.116)\end{array}$ & $\begin{array}{l}-0.003 \\
(0.008)\end{array}$ & $\begin{array}{c}0.005 \\
(0.074)\end{array}$ & $\begin{array}{l}0.005 \\
(0.007)\end{array}$ \\
\hline Other farmers & $\begin{array}{l}0.230 \\
(0.422)\end{array}$ & $\begin{array}{c}-0.127 * * * \\
(0.027)\end{array}$ & $\begin{array}{c}0.252 \\
(0.435)\end{array}$ & $\begin{array}{c}-0.149 * * * \\
(0.028)\end{array}$ & $\begin{array}{c}0.177 \\
(0.382)\end{array}$ & $\begin{array}{c}-0.073^{* * *} \\
(0.026)\end{array}$ & $\begin{array}{l}0.033 \\
(0.178)\end{array}$ & $\begin{array}{c}-0.019 * \\
(0.011)\end{array}$ & $\begin{array}{c}0.070 \\
(0.256)\end{array}$ & $\begin{array}{c}-0.046 * * * \\
(0.016)\end{array}$ \\
\hline Input shops & $\begin{array}{l}0.070 \\
(0.256)\end{array}$ & $\begin{array}{l}-0.016 \\
(0.018)\end{array}$ & $\begin{array}{c}0.146 \\
(0.354)\end{array}$ & $\begin{array}{c}-0.081 * * * \\
(0.022)\end{array}$ & $\begin{array}{c}0.446 \\
(0.498)\end{array}$ & $\begin{array}{c}-0.190 * * * \\
(0.035)\end{array}$ & $\begin{array}{l}0.000 \\
(0.000)\end{array}$ & $\begin{array}{l}0.005 \\
(0.004)\end{array}$ & $\begin{array}{c}0.011 \\
(0.104)\end{array}$ & $\begin{array}{c}0.000 \\
(0.008)\end{array}$ \\
\hline $\mathrm{N}$ & 369 & 737 & 369 & 737 & 369 & 737 & 369 & 737 & 369 & 737 \\
\hline
\end{tabular}

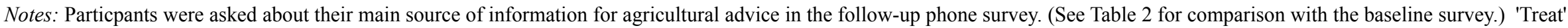

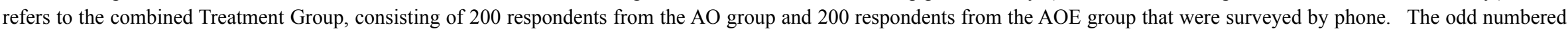

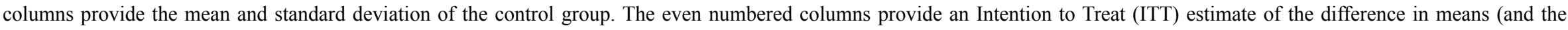
robust standard error) between the treatment group and the control group. $* * *$ significant at $1 \%$ level; ** significant at $5 \%$ level; * significant at $10 \%$ level. 
Table 6-Pesticide Purchases

\begin{tabular}{|c|c|c|c|c|}
\hline Cell contents: & $\begin{array}{r}\text { Control } \\
\text { Mean } \\
(1) \\
\end{array}$ & $\begin{array}{r}\text { Treat } \\
(2) \\
\end{array}$ & $\begin{array}{r}\text { Post } \\
\text { (3) } \\
\end{array}$ & $\begin{array}{r}\text { Treat*Post } \\
(4) \\
\end{array}$ \\
\hline Did you purchase Monocrotophos? & $\begin{array}{r}0.839 \\
(0.368)\end{array}$ & $\begin{array}{l}-0.006 \\
(0.029)\end{array}$ & $\begin{array}{l}0.087 \text { *** } \\
(0.027)\end{array}$ & $\begin{array}{r}0.006 \\
(0.033)\end{array}$ \\
\hline Qty. Purchased (Litres) & $\begin{array}{r}2.722 \\
(3.745)\end{array}$ & $\begin{array}{r}0.172 \\
(0.226)\end{array}$ & $\begin{array}{l}1.299 * * * \\
(0.230)\end{array}$ & $\begin{array}{l}-0.379 \\
(0.263)\end{array}$ \\
\hline Total Amount Spent* (Rs.) & $\begin{array}{r}429.786 \\
(1031.372)\end{array}$ & $\begin{array}{l}106.341 \\
(76.949)\end{array}$ & $\begin{array}{l}1002.166 \text { *** } \\
(86.383)\end{array}$ & $\begin{array}{l}-281.230 * * \\
(121.947)\end{array}$ \\
\hline Did you purchase Imidachloprid? & $\begin{array}{r}0.474 \\
(0.500)\end{array}$ & $\begin{array}{r}0.015 \\
(0.038)\end{array}$ & $\begin{array}{l}-0.084 * * \\
(0.037)\end{array}$ & $\begin{array}{l}0.107 \text { ** } \\
(0.045)\end{array}$ \\
\hline Qty. Purchased (Litres) & $\begin{array}{r}0.501 \\
(0.983)\end{array}$ & $\begin{array}{r}0.075 \\
(0.082)\end{array}$ & $\begin{array}{r}0.028 \\
(0.074)\end{array}$ & $\begin{array}{r}0.016 \\
(0.116)\end{array}$ \\
\hline Total Amount Spent* (Rs.) & $\begin{array}{r}557.003 \\
(1229.002)\end{array}$ & $\begin{array}{r}77.613 \\
(110.587)\end{array}$ & $\begin{array}{r}-127.099 \\
(84.328)\end{array}$ & $\begin{array}{r}-54.739 \\
(132.666)\end{array}$ \\
\hline Did you purchase Acetamaprid? & $\begin{array}{r}0.245 \\
(0.430)\end{array}$ & $\begin{array}{l}-0.019 \\
(0.026)\end{array}$ & $\begin{array}{l}0.163 \text { *** } \\
(0.036)\end{array}$ & $\begin{array}{r}0.038 \\
(0.037)\end{array}$ \\
\hline Qty. Purchased (Litres) & $\begin{array}{r}0.099 \\
(0.401)\end{array}$ & $\begin{array}{r}0.001 \\
(0.030)\end{array}$ & $\begin{array}{l}0.268 \text { *** } \\
(0.058)\end{array}$ & $\begin{array}{l}-0.055 \\
(0.056)\end{array}$ \\
\hline Total Amount Spent* (Rs.) & $\begin{array}{r}154.957 \\
(562.420)\end{array}$ & $\begin{array}{r}-51.524 \\
(50.012)\end{array}$ & $\begin{array}{l}107.938 * \\
(59.402)\end{array}$ & $\begin{array}{r}436.533 \\
(479.543)\end{array}$ \\
\hline Did you purchase Acephate? & $\begin{array}{r}0.887 \\
(0.317)\end{array}$ & $\begin{array}{r}0.006 \\
(0.022)\end{array}$ & $\begin{array}{r}0.024 \\
(0.023)\end{array}$ & $\begin{array}{l}-0.011 \\
(0.025)\end{array}$ \\
\hline Qty. Purchased (Litres) & $\begin{array}{r}2.438 \\
(2.840)\end{array}$ & $\begin{array}{r}0.117 \\
(0.221)\end{array}$ & $\begin{array}{l}1.011 \text { *** } \\
(0.225)\end{array}$ & $\begin{array}{l}-0.365 \\
(0.240)\end{array}$ \\
\hline Total Amount Spent* (Rs.) & $\begin{array}{r}1187.966 \\
(1382.354)\end{array}$ & $\begin{array}{r}131.281 \\
(110.463)\end{array}$ & $\begin{array}{r}88.215 \\
(95.174)\end{array}$ & $\begin{array}{l}-237.986 * * \\
(119.456)\end{array}$ \\
\hline $\begin{array}{l}\text { Village Fixed Effects } \\
\mathrm{N} \\
{ }_{\mathrm{N}} \mathrm{N}\end{array}$ & $\begin{array}{r}- \\
380 \\
363\end{array}$ & Yes & Yes & $\begin{array}{l}\text { Yes } \\
767 \\
731\end{array}$ \\
\hline
\end{tabular}

Notes:Particpants were asked about their pesticide purchases in the follow-up phone survey. Expenditure data are reported in rupees. ${ }^{*} \mathrm{~N}$ refers to the subset of respondents for whom pesticide purchasing data are available . 'Treat' refers to the combined Treatment Group, consisting of 200 respondents from the AO group and 200 respondents from the AOE group that were surveyed by phone.The columns above report regression coefficients from a Difference-inDifference specification, with the coefficient on Treat*Post giving the estimated treatment effect of assignment in to the combined $(\mathrm{AO}+\mathrm{AOE})$ treatment group relative to the control goup. Robust standard errors are reported below coefficient estimates. $* * *$ significant at $1 \%$ level; ** significant at $5 \%$ level; * significant at $10 \%$ level. 
Table 7-Pesticide Usage

\begin{tabular}{|c|c|c|c|c|c|c|}
\hline Cell contents: & $\begin{array}{c}\text { Control } \\
\text { Mean } \\
(1)\end{array}$ & $\begin{array}{l}\text { Treat } \\
(2) \\
\end{array}$ & $\begin{array}{l}\text { Post } \\
\text { (3) } \\
\end{array}$ & & $\begin{array}{c}\text { Treat*Post } \\
\text { (4) }\end{array}$ & \\
\hline Have you used Monocrotophos? & $\begin{array}{c}0.700 \\
(0.459)\end{array}$ & $\begin{array}{c}-0.024 \\
(0.038)\end{array}$ & $\begin{array}{c}0.224 \\
(0.035)\end{array}$ & $* * *$ & $\begin{array}{c}0.027 \\
(0.045)\end{array}$ & \\
\hline Quantity applied (L) & $\begin{array}{c}2.096 \\
(3.036)\end{array}$ & $\begin{array}{c}0.120 \\
(0.250)\end{array}$ & $\begin{array}{c}1.820 \\
(0.298)\end{array}$ & $* * *$ & $\begin{array}{l}-0.417 \\
(0.322)\end{array}$ & \\
\hline Intensity of usage (L/Acre) & $\begin{array}{c}0.571 \\
(0.884)\end{array}$ & $\begin{array}{c}0.000 \\
(0.053)\end{array}$ & $\begin{array}{c}0.300 \\
(0.074)\end{array}$ & $* * *$ & $\begin{array}{l}-0.040 \\
(0.082)\end{array}$ & \\
\hline Have you used Imidachlorpid? & $\begin{array}{c}0.434 \\
(0.496)\end{array}$ & $\begin{array}{c}0.033 \\
(0.037)\end{array}$ & $\begin{array}{l}-0.045 \\
(0.040)\end{array}$ & & $\begin{array}{c}0.086 \\
(0.047)\end{array}$ & $*$ \\
\hline Quantity applied (L) & $\begin{array}{c}0.206 \\
(0.878)\end{array}$ & $\begin{array}{c}0.011 \\
(0.073)\end{array}$ & $\begin{array}{c}0.312 \\
(0.087)\end{array}$ & $* * *$ & $\begin{array}{c}0.093 \\
(0.105)\end{array}$ & \\
\hline Intensity of usage (L/Acre) & $\begin{array}{c}0.061 \\
(0.308)\end{array}$ & $\begin{array}{l}-0.015 \\
(0.014)\end{array}$ & $\begin{array}{c}0.051 \\
(0.019)\end{array}$ & $* * *$ & $\begin{array}{c}0.037 \\
(0.019)\end{array}$ & $* *$ \\
\hline Have you used Acetamaprid? & $\begin{array}{c}0.184 \\
(0.388)\end{array}$ & $\begin{array}{c}0.006 \\
(0.026)\end{array}$ & $\begin{array}{c}0.224 \\
(0.037)\end{array}$ & $* * *$ & $\begin{array}{c}0.017 \\
(0.037)\end{array}$ & \\
\hline Quantity applied (L) & $\begin{array}{c}0.040 \\
(0.528)\end{array}$ & $\begin{array}{c}0.000 \\
(0.038)\end{array}$ & $\begin{array}{c}0.307 \\
(0.057)\end{array}$ & $* * *$ & $\begin{array}{l}-0.019 \\
(0.065)\end{array}$ & \\
\hline Intensity of usage (L/Acre) & $\begin{array}{c}0.010 \\
(0.093)\end{array}$ & $\begin{array}{c}0.002 \\
(0.009)\end{array}$ & $\begin{array}{c}0.066 \\
(0.011)\end{array}$ & $* * *$ & $\begin{array}{l}-0.007 \\
(0.013)\end{array}$ & \\
\hline Have you used Acephate? & $\begin{array}{c}0.868 \\
(0.338)\end{array}$ & $\begin{array}{l}-0.017 \\
(0.020)\end{array}$ & $\begin{array}{c}0.034 \\
(0.023)\end{array}$ & & $\begin{array}{c}0.015 \\
(0.026)\end{array}$ & \\
\hline Quantity applied (Kg) & $\begin{array}{c}1.036 \\
(2.863)\end{array}$ & $\begin{array}{l}-0.142 \\
(0.198)\end{array}$ & $\begin{array}{c}2.307 \\
(0.294)\end{array}$ & $* * *$ & $\begin{array}{l}-0.230 \\
(0.304)\end{array}$ & \\
\hline Intensity of usage (L/Acre) & $\begin{array}{c}0.274 \\
(0.709)\end{array}$ & $\begin{array}{l}-0.023 \\
(0.043)\end{array}$ & $\begin{array}{c}0.447 \\
(0.056)\end{array}$ & $* * *$ & $\begin{array}{l}-0.030 \\
(0.057)\end{array}$ & \\
\hline Village Fixed Effects & - & Yes & Yes & & Yes & \\
\hline $\mathrm{N}$ & 380 & & & & 767 & \\
\hline
\end{tabular}

Notes: Participants were asked about their pesticide usage in the follow-up phone survey. 'Treat' refers to the combined Treatment Group, consisting of 200 respondents from the AO group and 200 respondents from the AOE group that were surveyed by phone. The columns above report regression coefficients from a Difference-inDifference specification, with the coefficient on Treat*Post giving the estimated treatment effect of assignment in to the combined $(\mathrm{AO}+\mathrm{AOE})$ treatment group relative to the control goup. Robust standard errors are reported below coefficient estimates. ${ }^{* *}$ significant at $1 \%$ level; $* *$ significant at $5 \%$ level; $*$ significant at $10 \%$ level. 
Table 8-Sowing Decisions

\begin{tabular}{|c|c|c|c|c|c|c|}
\hline \multirow{4}{*}{$\begin{array}{l}\text { Did you plant wheat this Rabi } 2011 ? \\
\end{array}$} & \multirow{4}{*}{$\begin{array}{c}\begin{array}{c}\text { Control } \\
\text { Mean } \\
(1)\end{array} \\
0.784 \\
(0.412)\end{array}$} & \multirow{2}{*}{$\begin{array}{r}\text { Treat } \\
(2) \\
\end{array}$} & \multirow{2}{*}{$\begin{array}{r}\text { Post } \\
(3) \\
\end{array}$} & \multicolumn{3}{|c|}{ Treat*Post } \\
\hline & & & & & (4) & \\
\hline & & -0.045 & -0.011 & & 0.029 & \\
\hline & & $(0.032)$ & $(0.046)$ & & $(0.044)$ & \\
\hline & 1.170 & 0.198 & -0.439 & $* * *$ & -0.200 & \\
\hline Total area of wheat planted in Rabi 2011 & $(1.316)$ & $(0.129)$ & $(0.112)$ & & $(0.139)$ & \\
\hline Did you plant cumin this Rabi $2011 ?$ & 0.425 & -0.030 & -0.152 & $* * *$ & 0.078 & $*$ \\
\hline (Before December 2011)* & $(0.495)$ & $(0.032)$ & $(0.033)$ & & $(0.043)$ & \\
\hline Total area of cumin planted in Rabi $2011 ?$ & 0.775 & -0.006 & -0.253 & $* * *$ & 0.249 & * \\
\hline (Before December 2011)* & $(1.441)$ & $(0.084)$ & $(0.085)$ & & $(0.129)$ & \\
\hline Did you plant cumin this Rabi $2011 ?$ & 0.429 & -0.029 & 0.439 & $* * *$ & 0.031 & \\
\hline (Before February 2012) & $(0.496)$ & $(0.031)$ & $(0.043)$ & & $(0.036)$ & \\
\hline Total area of cumin planted in Rabi $2011 ?$ & 0.780 & -0.020 & -0.013 & & 0.200 & \\
\hline (Before February 2012) & $(1.430)$ & $(0.082)$ & $(0.097)$ & & $(0.123)$ & \\
\hline Village Fixed Effects & - & Yes & Yes & & Yes & \\
\hline $\mathrm{N}$ & 380 & & & & 767 & \\
\hline$* \mathrm{~N}$ & 369 & & & & 737 & \\
\hline
\end{tabular}

Notes:Participants were asked about their sowing decisions in the follow-up phone survey. $\mathrm{N}$ refers to the sample for whom baseline, and phone survey round 1 and 2 data are availble. ${ }^{*} \mathrm{~N}$ refers to the sample for whom baseline and phone survey round 1 data are availbale. 'Treat' refers to the combined Treatment Group, consisting of 200 respondents from the AO group and 200 respondents from the AOE group that were surveyed by phone. The columns above report regression coefficients from a Difference-in-Difference specification, with the coefficient on Treat*Post giving the estimated treatment effect of assignment in to the combined (AO+AOE) treatment group relative to the control goup. Robust standard errors are reported below coefficient estimates. ${ }^{* * *}$ significant at $1 \%$ level; ** significant at $5 \%$ level; * significant at $10 \%$ level. 
Table 9-Agricultural Knowledge Score

\begin{tabular}{|c|c|c|c|c|c|c|}
\hline \multirow[b]{3}{*}{ Cell contents: } & \multicolumn{3}{|c|}{ Baseline Survey } & \multicolumn{3}{|c|}{ Follow-up Phone Survey } \\
\hline & Control & Treat-Control & Treat-Control & Control & Treat-Control & Treat-Control \\
\hline & $\begin{array}{l}\text { Mean } \\
\text { (1) }\end{array}$ & $\begin{array}{l}\text { ITT } \\
(2)\end{array}$ & $\begin{array}{l}\text { ITT } \\
(3)\end{array}$ & $\begin{array}{l}\text { Mean } \\
\text { (4) }\end{array}$ & $\begin{array}{l}\text { ITT } \\
(5)\end{array}$ & $\begin{array}{c}\text { ITT } \\
\text { (6) }\end{array}$ \\
\hline Total & $\begin{array}{c}0.289 \\
(0.212)\end{array}$ & $\begin{array}{l}-0.002 \\
(0.013)\end{array}$ & $\begin{array}{l}-0.001 \\
(0.014)\end{array}$ & $\begin{array}{c}0.350 \\
(0.173)\end{array}$ & $\begin{array}{c}0.010 \\
(0.013)\end{array}$ & $\begin{array}{c}0.008 \\
(0.011)\end{array}$ \\
\hline Cotton-related & $\begin{array}{l}0.585 \\
0.493\end{array}$ & $\begin{array}{l}0.023 \\
0.030\end{array}$ & $\begin{array}{l}0.024 \\
0.034\end{array}$ & $\begin{array}{c}0.576 \\
(0.380)\end{array}$ & $\begin{array}{c}0.026 \\
(0.027)\end{array}$ & $\begin{array}{l}0.025 \\
(0.022)\end{array}$ \\
\hline Fertilizer-related & $\begin{array}{c}0.162 \\
(0.279)\end{array}$ & $\begin{array}{l}-0.006 \\
(0.017)\end{array}$ & $\begin{array}{c}-0.004 \\
(0.016)\end{array}$ & $\begin{array}{c}0.321 \\
(0.200)\end{array}$ & $\begin{array}{l}-0.013 \\
(0.015)\end{array}$ & $\begin{array}{l}-0.015 \\
(0.014)\end{array}$ \\
\hline Pesticide-related & $\begin{array}{c}0.284 \\
(0.451)\end{array}$ & $\begin{array}{l}0.003 \\
(0.028)\end{array}$ & $\begin{array}{c}0.003 \\
(0.028)\end{array}$ & $\begin{array}{c}0.202 \\
(0.257)\end{array}$ & $\begin{array}{l}-0.005 \\
(0.019)\end{array}$ & $\begin{array}{l}-0.008 \\
(0.014)\end{array}$ \\
\hline Cumin-related & $\begin{array}{c}0.254 \\
(0.436)\end{array}$ & $\begin{array}{l}-0.024 \\
(0.026)\end{array}$ & $\begin{array}{l}-0.024 \\
(0.025)\end{array}$ & $\begin{array}{c}0.340 \\
(0.474)\end{array}$ & $\begin{array}{c}0.120 * * * \\
(0.036)\end{array}$ & $\begin{array}{c}0.123 * * * \\
(0.035)\end{array}$ \\
\hline Fixed Effects & - & No & Yes & - & No & Yes \\
\hline $\mathrm{N}$ & 398 & 1200 & 1200 & 368 & 736 & 736 \\
\hline
\end{tabular}

Notes: Participants were asked agricultural knolwedge questions and knolwedge score was computed in term of the proportion of questions correctly answered. 'Treat' refers to the combined Treatment Group, consisting of 200 respondents from the AO group and 200 respondents from the AOE group that were surveyed by phone. Columns (1) and (6) provide the mean and standard deviation of the control group. Columns (2), (3), (5) and (6) provide an Intention to Treat (ITT) estimate of the difference in means (and robust standard errors) between the treatment group and the control group. $* * *$ significant at $1 \%$ level; ** significant at 5\% level; * significant at $10 \%$ level. 
Table 10: Heterogenous Treatment Effects by Education

\begin{tabular}{|c|c|c|c|c|c|c|}
\hline & $\begin{array}{c}\text { Treat } \\
(1)\end{array}$ & & $\begin{array}{c}\text { Edu } \\
(2) \\
\end{array}$ & & $\begin{array}{c}\text { Treat*Edu } \\
\text { (3) }\end{array}$ & \\
\hline \multicolumn{7}{|l|}{$\overline{A O \text { Usage }}$} \\
\hline Called AO & $\begin{array}{c}0.575 \\
(0.029)\end{array}$ & $* * *$ & $\begin{array}{c}0.022 \\
(0.015)\end{array}$ & & $\begin{array}{c}0.022 \\
(0.038)\end{array}$ & \\
\hline Minutes of AO Usage & $\begin{array}{c}82.358 \\
(12.048)\end{array}$ & $* * *$ & $\begin{array}{c}2.774 \\
(4.806)\end{array}$ & & $\begin{array}{c}17.580 \\
(14.174)\end{array}$ & \\
\hline Number of Calls to AO & $\begin{array}{c}5.697 \\
(0.868)\end{array}$ & $* * *$ & $\begin{array}{c}0.150 \\
(0.268)\end{array}$ & & $\begin{array}{c}1.933 \\
(1.137)\end{array}$ & $*$ \\
\hline Minutes listened to push calls & $\begin{array}{c}0.634 \\
(0.017)\end{array}$ & $* * *$ & $\begin{array}{c}0.008 \\
(0.007)\end{array}$ & & $\begin{array}{c}0.041 \\
(0.020)\end{array}$ & $* *$ \\
\hline Asked a Question on AO & $\begin{array}{c}0.264 \\
(0.031)\end{array}$ & $* * *$ & $\begin{array}{c}0.019 \\
(0.015)\end{array}$ & & $\begin{array}{c}0.078 \\
(0.034)\end{array}$ & $* *$ \\
\hline \multicolumn{7}{|l|}{ Knowledge Questions } \\
\hline Total Questions Right & $\begin{array}{l}-0.027 \\
(0.018)\end{array}$ & & $\begin{array}{c}0.048 \\
(0.018)\end{array}$ & $* * *$ & $\begin{array}{l}0.074 \\
(0.025)\end{array}$ & $* * *$ \\
\hline Cotton-related & $\begin{array}{l}-0.007 \\
(0.040)\end{array}$ & & $\begin{array}{c}0.107 \\
(0.040)\end{array}$ & $* * *$ & $\begin{array}{c}0.071 \\
(0.054)\end{array}$ & \\
\hline Fertilizer-related & $\begin{array}{l}-0.048 \\
(0.021)\end{array}$ & $* *$ & $\begin{array}{c}0.030 \\
(0.021)\end{array}$ & & $\begin{array}{l}0.070 \\
(0.029)\end{array}$ & $* *$ \\
\hline Pesticide-related & $\begin{array}{l}-0.033 \\
(0.027)\end{array}$ & & $\begin{array}{c}0.038 \\
(0.027)\end{array}$ & & $\begin{array}{l}0.055 \\
(0.037)\end{array}$ & \\
\hline Cumin-related & $\begin{array}{c}0.047 \\
(0.052)\end{array}$ & & $\begin{array}{c}0.037 \\
(0.050)\end{array}$ & & $\begin{array}{l}0.141 \\
(0.071)\end{array}$ & $* *$ \\
\hline $\mathrm{N}$ & & & & & 1200 & \\
\hline
\end{tabular}

Notes: Regressions are presented in rows for each dependent variable. 'Treat' refers to the combined Treatment Group, consisting of 200 respondents from the AO group and 200 respondents from the AOE group that were surveyed by phone. Columns (1)-(3) present the main effects and interactions for the treatment group and above-median education (Edu.. The interaction columns report $\beta_{3}$ from the following specification: $Y_{i}=\alpha+\beta_{1}$ Treat $_{i}+\beta_{2} \mathrm{I}(\mathrm{Edu}>\mathrm{Median})+$ $\beta_{3}$ Treat $^{*} \mathrm{I}(\mathrm{Edu}>$ Median $)+\varepsilon$ i. Robust standard errors are reported in parentheses. $* * *$ significant at $1 \%$ level; ** significant at $5 \%$ level; * significant at $10 \%$ level. 


\begin{tabular}{|c|c|c|c|c|c|}
\hline \multicolumn{6}{|c|}{ Appendix Table A1: Experimental Design and Response Rates } \\
\hline & Control Group & AO Only & $\mathrm{AO}+$ Extension & Treat & Total \\
\hline Paper Survey Sample & 398 & 399 & 403 & 398 & 1200 \\
\hline Respondents Reached, Baseline & 398 & 399 & 403 & 398 & 1200 \\
\hline \% Respondents Reached & $100 \%$ & $100 \%$ & $100 \%$ & $100 \%$ & $100 \%$ \\
\hline Target Phone Survey Sample & 398 & 200 & 200 & 398 & 798 \\
\hline Respondents Reached, Round 1 & 369 & 184 & 184 & 368 & 737 \\
\hline \% Respondents Reached & $93 \%$ & $92 \%$ & $92 \%$ & $92 \%$ & $92 \%$ \\
\hline Respondents Reached, Round 2 & 367 & 184 & 187 & 371 & 738 \\
\hline \% Respondents Reached & $92 \%$ & $92 \%$ & $94 \%$ & $93 \%$ & $92 \%$ \\
\hline
\end{tabular}

Notes: A baseline survey was administered to 1200 respondents in June/July 2011. Following this, a subset of this sample, 200 respondents from the AO Only group, 200 from the AO+Extension group and the entire control group were surveyed by phone. Round 1 of the phone survey was completed in December, 2011, while Round 2 was completed in March, 2012. 
Table A2-Pest Attacks

\begin{tabular}{|c|c|c|}
\hline & $\begin{array}{l}\text { Control } \\
\text { Mean } \\
(1)\end{array}$ & $\begin{array}{c}\text { Treat } \\
(\mathrm{AO}+\mathrm{AOE}) \\
(2)\end{array}$ \\
\hline Experienced a pest attack? & 0.967 & 0.966 \\
\hline Experienced a bollworm (B) attack? & 0.147 & 0.117 \\
\hline Experienced a sucking pest (SP) attack? & 0.939 & 0.972 \\
\hline Experienced spotted bollworm attack? (B) & 0.050 & 0.050 \\
\hline Experienced pink bollworm attack? (B) & 0.008 & 0.006 \\
\hline Experienced heliothis attack? (B) & 0.111 & 0.084 \\
\hline Experienced aphid attack? (SP) & 0.512 & 0.453 \\
\hline Experienced jassid attack? (SP) & 0.723 & 0.715 \\
\hline Experienced thrips attack? (SP) & 0.111 & 0.117 \\
\hline Experienced whitefly attack? (SP) & 0.670 & 0.715 \\
\hline Experienced mealybug attack? (SP) & 0.526 & 0.581 \\
\hline $\mathrm{N}$ & 368 & 184 \\
\hline
\end{tabular}

Notes: Reported pest attacks are overwhelmingly about sucking pest attacks. 'Treat' refers to the combined treatment Group, consisting of 200 respondents from the $\mathrm{AO}$ group and 200 respondents from the $\mathrm{AOE}$ group that were surveyed by phone. 
Table A3 - Characteristics of Attritors from Phone Survey By Initial Treatment Assignment

\begin{tabular}{|c|c|c|c|c|c|}
\hline Attritors from & $\begin{array}{c}\text { Control } \\
\text { Mean } \\
\text { Phone R1 } \\
\text { (1) }\end{array}$ & $\begin{array}{c}\text { Treat-Control } \\
\text { Phone R1 } \\
\text { (2) }\end{array}$ & $\begin{array}{c}\text { Control } \\
\text { Mean } \\
\text { Phone R2 } \\
\text { (3) }\end{array}$ & $\begin{array}{l}\text { Phone R2 } \\
\text { (4) }\end{array}$ & \\
\hline Age & $\begin{array}{l}35.37 \\
(9.05)\end{array}$ & $\begin{array}{l}2.22 \\
(3.16)\end{array}$ & $\begin{array}{c}32.790 \\
(9.300)\end{array}$ & $\begin{array}{c}3.658 \\
(2.882)\end{array}$ & \\
\hline Years of Education & $\begin{array}{l}2.59 \\
(2.99)\end{array}$ & $\begin{array}{c}0.34 \\
(0.92)\end{array}$ & $\begin{array}{r}3.806 \\
(3.351)\end{array}$ & $\begin{array}{l}-0.289 \\
(0.946)\end{array}$ & \\
\hline Landholdings - Acres & $\begin{array}{l}4.58 \\
(3.84)\end{array}$ & $\begin{array}{l}-0.05 \\
(0.85)\end{array}$ & $\begin{array}{r}6.310 \\
(6.591)\end{array}$ & $\begin{array}{c}0.366 \\
(1.544)\end{array}$ & \\
\hline Agricultural Income ('000s) & $\begin{array}{c}147.26 \\
(151.72)\end{array}$ & $\begin{array}{l}-30.93 \\
(33.47)\end{array}$ & $\begin{array}{r}161763 \\
(167434)\end{array}$ & $\begin{array}{c}37707 \\
(43746)\end{array}$ & \\
\hline Planted Cotton in K'10 & $\begin{array}{l}1.00 \\
(0.00)\end{array}$ & $\begin{array}{l}-0.03 \\
(0.04)\end{array}$ & $\begin{array}{r}1.000 \\
(0.000)\end{array}$ & $\begin{array}{l}-0.069 \\
(0.048)\end{array}$ & \\
\hline Area of Cotton Planted & $\begin{array}{l}4.33 \\
(4.04)\end{array}$ & $\begin{array}{l}-0.54 \\
(0.85)\end{array}$ & $\begin{array}{r}5.499 \\
(4.960)\end{array}$ & $\begin{array}{l}-0.223 \\
(1.173)\end{array}$ & \\
\hline Planted Wheat in $\mathrm{K}^{\prime} 10$ & $\begin{array}{c}0.667 \\
(0.480)\end{array}$ & $\begin{array}{c}0.092 \\
(0.122)\end{array}$ & $\begin{array}{c}0.645 \\
(0.486)\end{array}$ & $\begin{array}{c}0.217 \\
(0.109)\end{array}$ & $* *$ \\
\hline Area of Wheat Planted & $\begin{array}{c}1.111 \\
(1.649)\end{array}$ & $\begin{array}{c}0.137 \\
(0.412)\end{array}$ & $\begin{array}{c}1.084 \\
(1.623)\end{array}$ & $\begin{array}{c}1.171 \\
(0.992)\end{array}$ & \\
\hline Planted Cumin in 2010 & $\begin{array}{c}0.407 \\
(0.501)\end{array}$ & $\begin{array}{c}0.179 \\
(0.134)\end{array}$ & $\begin{array}{r}0.355 \\
(0.486)\end{array}$ & $\begin{array}{c}0.300 \\
(0.125)\end{array}$ & $* *$ \\
\hline Area Cumin Planted in 2010 & $\begin{array}{c}0.563 \\
(0.808)\end{array}$ & $\begin{array}{c}0.194 \\
(0.235)\end{array}$ & $\begin{array}{r}0.445 \\
(0.698)\end{array}$ & $\begin{array}{c}0.858 \\
(0.339)\end{array}$ & $* *$ \\
\hline $\mathrm{N}$ & 27 & 56 & 31 & 60 & \\
\hline
\end{tabular}

Notes: This table compares baseline characterstics of the 27 of 398 control, and 29 of 400 treatment individuals who could not be reached in the first round of the phone survey that concluded in December, 2012 in Columns $1 \& 2$ and the analogous statistics for the 31 of 398 control, and 29 of 400 treatment individuals who could not be reached in the second round of the phone survey that concluded in February 2012. 
Table A4: Balance Check in Baseline Characteristics

\begin{tabular}{|c|c|c|c|c|c|c|c|c|c|}
\hline Comparison & $\#$ & $\begin{array}{c}\text { AOE vs. } \\
\text { Variables } \\
\end{array}$ & $\begin{array}{l}\text { Control } \\
\% \text { of Total } \\
\text { \% }\end{array}$ & \# & $\begin{array}{r}\text { AO vs. } \\
\text { (2 } \\
\text { Variables } \\
\end{array}$ & $\begin{array}{l}\overline{\text { Control }} \\
\% \text { of Total } \\
\end{array}$ & $\#$ & $\begin{array}{r}\text { Treat vs. } \\
\text { (3) } \\
\text { Variables } \\
\end{array}$ & $\begin{array}{l}\text { Control } \\
\% \text { of Total } \\
\end{array}$ \\
\hline Significantly Different at $1 \%$ Level & & 18 & 0.009 & & 19 & 0.010 & & 19 & 0.010 \\
\hline Significantly Different at 5\% Level & & 72 & 0.037 & & 81 & 0.042 & & 81 & 0.042 \\
\hline Significantly Different at $10 \%$ Level & & 140 & 0.073 & & 162 & 0.084 & & 162 & 0.084 \\
\hline $\begin{array}{l}\text { Total No. of Variables } \\
\text { in Dataset }\end{array}$ & & 1923 & & & 1923 & & & 1923 & \\
\hline
\end{tabular}

Notes: This table conducts an overall test of balance between the two treatment arms (AO and AOE) and the control group (Columns 1 and 2) using all baseline data collected. We also report balance in the phone survey sample that consists of half the respondents in each of the treatment arms and the control group (Column 3). In each case, we report the number of variables and the percentage of the total number of variables that are significantly different at traditional levels of significance. 